\title{
Em nome da coesão: parlamentares e comissionados nas executivas nacionais dos partidos brasileiros
}

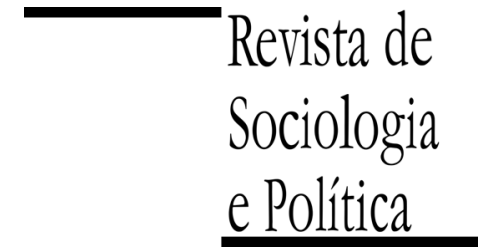

DOI 10.1590/1678-987314225208

\author{
Pedro Floriano Ribeiro
}

\begin{abstract}
RESUMO
Quase nada sabemos sobre as cúpulas dirigentes dos partidos políticos brasileiros, espaços de coagulação de disputas e deliberações acerca de aspectos relevantes da vida política nacional. O objetivo do trabalho é começar a abrir a caixa preta desses espaços, delineando-se um perfil das elites dirigentes dos principais partidos brasileiros. São utilizados dados inéditos acerca das comissões executivas nacionais formadas entre 1980 e 2013, dos sete maiores partidos: PT, PSB, PDT, PMDB, PSDB, PP e DEM. Os dados sobre as executivas foram obtidos junto ao Tribunal Superior Eleitoral (TSE), DHBB (Fundação Getúlio Vargas) e junto aos próprios partidos. Além de apontar as diferenças entre os partidos no tocante ao peso da "face pública" nas executivas (mandatários eleitos e ocupantes de cargos de confiança), avaliou-se estatisticamente a força explicativa de algumas variáveis para compreender os padrões e diferenças identificados: ideologia e origem do partido, sua força eleitoral/parlamentar, e participação no governo federal. Indo além dos números, são apresentados alguns nomes de dirigentes que se destacam nas cúpulas partidárias, sublinhando que o núcleo decisório das máquinas (secretaria geral, de finanças etc.) pode apresentar uma fisionomia um pouco distinta das executivas como um todo. Um modelo explicativo integrado deu conta de explicar a maior parte da variabilidade observada, sugerindo a origem partidária (se interna ou não ao parlamento) como principal variável explicativa. Os partidos de origem interna (que são os de centro e direita) tendem a ter executivas de perfil mais parlamentarizado, enquanto os de origem não interna (os de esquerda) possuem menos parlamentares, com as executivas do PT se destacando por absorverem a maior quantidade de dirigentes sem histórico de cargos. Os resultados reforçam a importância de se atentar para o modelo originário de cada partido, e contestam uma das suposições mais arraigadas na literatura: a de que as instâncias centrais dos partidos brasileiros seriam monoliticamente controladas por deputados federais e senadores. É mais apropriado falar em elites partidárias do que em uma elite unida. Por trás da presença constante de parlamentares e ocupantes de cargos de confiança nas executivas está a busca de coesão e articulação entre distintos elementos do corpo partidário, tanto em sentido horizontal (direção nacional, bancadas no Congresso e governo federal) como no vetor vertical-federativo (direção nacional, bancadas, gestões e diretórios subnacionais).
\end{abstract}

PALAVRAS-CHAVE: partidos políticos; elites políticas; modelo originário; executivas nacionais; ideologia.

Recebido em 20 de Fevereiro de 2014. Aprovado em 6 de Novembro de 2014.

\section{Introdução: por que estudar as elites partidárias? ${ }^{1}$}

${ }^{1} \mathrm{O}$ artigo resulta de projeto financiado pela FAPESP: Estado, partidos e sociedade no Brasil contemporâneo (12/05132-0). A coleta e organização dos dados contou com o diligente trabalho de Brina Leveguen, bolsista de iniciação científica da FAPESP. Além do evento em Curitiba, um esboço foi apresentado em seminário na Fundação Getúlio Vargas (EAESP) em agosto de 2014. Agradeço os comentários realizados pelos participantes desses eventos, e às
"Os dados nos são necessários; se são quantificados, melhor; se muito numerosos, melhor ainda. A maioria dos dados desse tipo são as estatísticas socioeconômicas: daí a difusão horizontal e periférica da política, que nos conduz a ver onde ela nasce, e não onde se coagula" (Sartori 1981, p. 200). Sabemos relativamente bastante sobre a origem do poder político no Brasil (por meio de estudos de comportamento eleitoral), e sobre alguns dos espaços em que a política se concretiza em decisões efetivas, como as arenas legislativas. No entanto, quase nada sabemos sobre as cúpulas dirigentes dos partidos políticos, também espaços de coagulação de disputas, negociações e deliberações acerca de aspectos relevantes da vida política nacional - como a costura de chapas e alianças para as eleições presidenciais, as decisões relativas ao apoio ou oposição ao governo federal, e as intervenções sobre diretórios e convenções estaduais e locais, com potencial para afetar (e até reverter) processos de seleção de candidatos nesses níveis. 
observações dos pareceristas da Revista de Sociologia e Política.
O objetivo deste trabalho é começar a abrir a caixa preta desses espaços de coagulação, delineando-se um perfil das elites dirigentes dos principais partidos brasileiros. Para tanto, são utilizados dados inéditos acerca das comissões executivas nacionais das sete maiores legendas do país: PT, PSB, PDT, PMDB, PSDB, PP e DEM. As direções partidárias são controladas por parlamentares? Qual é o peso representado pelos ocupantes de cargos públicos não eletivos nessas cúpulas? O núcleo decisório de cada executiva (cargos mais relevantes, como finanças etc.) possui o mesmo perfil, ou haveria o predomínio de burocratas dedicados apenas ao partido? Além de apontar as diferenças entre os partidos, procurou-se avaliar o impacto de algumas variáveis sobre as variações observadas - sem a pretensão, no entanto, de afirmar respostas peremptórias acerca desses fatores explicativos.

A análise dos dados se estruturou ao redor de quatro hipóteses. Algumas delas podem parecer algo óbvias; mas como o conhecimento acerca das elites dirigentes dos partidos brasileiros é quase nulo, mesmo o óbvio suposto ainda carecia de comprovação empírica, passando da especulação à verificação.

(i) Os partidos de esquerda tendem a ser menos dominados pelos ocupantes de cargos eletivos do que os partidos de centro e direita, na medida em que conformam, tradicionalmente, um padrão de relacionamento de maior controle sobre bancadas e gestões, concebidas como partidárias - sendo que o padrão inverso seria típico dos partidos de centro e direita, muitas vezes criados como instrumentos das bancadas. Esse padrão da esquerda é potencializado nos casos em que o partido possui uma origem externa ao parlamento - que é a regra ao longo da história, com algumas exceções (Duverger 1987; Van Biezen 2000; Bolleyer \& Gauja 2013).

(ii) A origem de um partido político, se interna ou externa ao parlamento, influencia no peso que os parlamentares terão nas instâncias dirigentes, mesmo depois de décadas da fundação da legenda. Partidos de origem interna tendem a ser controlados, desde o início, por parlamentares, enquanto os de origem externa tendem a mesclar esse predomínio com dirigentes de outro perfil, ao menos nos primeiros anos (Duverger 1987; Panebianco 1995). A inclusão da origem como variável também permite inserir o fator temporal na discussão. É razoável esperar que o perfil da executiva $\mathrm{N}$ tenha impacto no perfil da executiva $\mathrm{N}+1$, e assim sucessivamente. Partidos que já nasceram altamente parlamentarizados tendem a continuar com esse perfil, seja porque os parlamentares já se constituíam em núcleos de poder independentes da máquina desde o início, porque conformaram uma estrutura decisória interna que lhes favorecia (como as regras de composição e permanência nas executivas) etc.

(iii) A participação do partido na coalizão de governo faz aumentar o peso de ocupantes de cargos públicos nas instâncias dirigentes, na medida em que os membros com postos na administração - ministros, secretários, dirigentes de empresas estatais etc. - passam a controlar recursos bastante valorizados (principalmente cargos na máquina pública), úteis nos jogos internos de poder. Essa presença tende a ser mais acentuada quando o partido chega ao governo pouco tempo após ser fundado: uma organização ainda não autônoma em relação ao entorno se torna correia de transmissão do governo com mais facilidade do que estruturas já institucionalizadas (Panebianco 1995; Van Biezen 2000).

(iv) Independentemente da participação no governo, existiria uma forte associação entre o tamanho da bancada do partido e o peso de mandatários eleitos (sobretudo parlamentares) nas cúpulas dirigentes, já que os políticos eleitos acumulam recursos de poder vitais à sobrevivência organizativa, e que são mobilizados como incentivos seletivos nas disputas internas. Nesse sentido, o tamanho da bancada na Câmara é tomada como variável proxy da força 
eleitoral/representativa do partido, ou seja: do peso dos políticos com mandato no conjunto partidário.

Por que o perfil das elites partidárias interessa como objeto de pesquisa? As direções nacionais absorvem em seus quadros dirigentes com distintos interesses, aspirações, origens e trajetórias, e em momentos diferentes da carreira. Há espaços para os políticos profissionais ampliarem e manterem sua influência interna, inclusive após fracassos eleitorais. Mas também há as necessidades de incorporar, no topo da máquina, diferentes modalidades de $e x$ pertise, e de conferir certa estabilidade no desempenho das atividades operacionais, contrapondo doses de continuidade ao dinamismo próprio dos políticos de carreira. A junção entre diferentes "categorias de carreira" nas direções nacionais responde ao desafio de conciliar mobilidade, regularidade e aspirações (cf. Eldersveld 1964, pp. 153-175).

Tomando o partido como um conjunto de subcoalizões, Eldersveld (idem, pp. 118-120, 160-172) interpreta essa multiplicidade de perfis como expressão dos distintos segmentos agrupados na agremiação, com a direção nacional refletindo a correlação de forças entre os grupos. Esse caráter multifacetado leva o autor a enxergar a direção como um agregado de elites partidárias, mais do que o lócus de uma elite coesa e integrada. Sem coesão e comunhão de interesses, fica prejudicada a hipótese michelsiana de um círculo restrito que controla o partido com mãos de ferro e de costas para o restante da organização. A falta de coesão, ao implicar na dispersão do controle das zonas de incerteza do partido, afeta a liberdade de ação da direção e sua capacidade de adaptar a organização a pressões, desafios e mudanças ambientais (Panebianco 1995).

O predomínio de uma categoria ou outra de dirigente na cúpula partidária também é um indicador dos padrões de recrutamento vigentes na organização. A presença maior de dirigentes sem histórico de cargos externos sugere um padrão vertical de integração das elites, no qual os indivíduos encontram canais para construir sua carreira de modo ascendente através da hierarquia do partido, em lugar de ingressarem diretamente no topo da estrutura (padrão horizontal). O tempo de filiação de cada dirigente (dado não trabalhado aqui) também ajuda a avaliar não apenas essa questão, mas também o grau de permeabilidade da máquina a indivíduos estranhos a ela (idem).

O perfil das elites partidárias pode dizer algo, também, sobre as conexões entre os partidos e o Estado brasileiro (que se dá através da patronagem, por exemplo). Em todos os sistemas partidários da história política brasileira, a forte dependência dos partidos em relação ao Estado foi a tônica. Por aqui as maiores agremiações sempre estiveram na órbita do Estado - desde a origem, dada no interior de aparelhos executivos e legislativos (a maioria), ou a partir do momento em que galgaram posições de comando no país (caso do PT). Salvo raras exceções, o acesso a recursos institucionais e financeiros decisivos à sobrevivência dos partidos sempre se deu em espaços estatais, e não nas esferas societárias. Por trás disso se situa o processo histórico brasileiro, em que uma organização burocrático-estatal centralizada e forte constituiu-se antes que a sociedade e os partidos, que se articulariam ao redor daquela (Souza 1983).

A dependência dos recursos estatais diretos (fundo partidário) e indiretos (horário no rádio e televisão), e os amplos espaços para patronagem partidária (distribuição de cargos a apoiadores e clientelas) nas máquinas públicas locais, estaduais e nacional deixam poucas dúvidas sobre as principais fontes de recursos das organizações partidárias do país (cf. Praça, Freitas \& Hoepers 2012; Ribeiro 2013b). A colonização de espaços da máquina pública por longos períodos - em especial os cargos mais altos dos ministérios e autarquias permite aos partidos a demarcação de territórios políticos, franqueando o acesso a clientelas específicas de políticas públicas. Essa estratégia tende a gerar 
dividendos eleitorais futuros, assegurando a atratividade do partido como parceiro importante em uma nova coalizão de governo: gera-se, assim, um círculo virtuoso de experiência governativa e fortalecimento organizacional (cf. Meneguello 1998).

O que é uma constante histórica no Brasil despontou, nas últimas décadas, como transformação do fenômeno partidário nas democracias mais antigas, com a erosão do conceito duvergeriano de partidos socialmente enraizados enquanto paradigma para avaliação das agremiações. Questionados quanto a sua legitimidade, desafiados pelos meios de comunicação, pelas novas mídias, e por atores e canais alternativos de mobilização e expressão, e perdidos em meio à diluição de clivagens tradicionais, os partidos contemporâneos enfrentam o descrédito e o afastamento de grande parte da população. Ao mesmo tempo, eles continuam dominando, quase sozinhos, as principais funções decisórias e governativas requeridas em um regime democrático: recrutamento para cargos eletivos e não eletivos, organização e suporte dos governos, policymaking etc. Ao refluxo no desempenho das funções representativas clássicas - articulação e canalização de demandas - não corresponde, assim, um recuo no exercício dos papéis processuais/institucionais, e os vínculos estatais substituem o enraizamento social como fonte principal de sobrevivência das organizações. Gera-se um círculo vicioso: frente ao alheamento do eleitorado, as elites políticas se ensimesmam nas máquinas partidárias e estatais, o que potencializa o descrédito perante a sociedade. Não haveria problemas nessa "adaptação evolutiva" se ela não comprometesse aquela que talvez seja a única especificidade dos partidos políticos: a capacidade de combinar justamente as funções representativas e processuais. Se não representam, há justificativas para seguir governando? Para Mair (2005; 2009), a ineficiência no exercício das funções representativas pode deslegitimar os papéis procedimentais: os partidos se veriam (ainda mais) deslegitimados, e a falta de atores alternativos viáveis comprometeria, em última instância, a própria democracia.

Nesse cenário de dependência estatal, os parlamentares dominam efetivamente as direções dos partidos brasileiros? Nos partidos criados a partir dos anos 1980 e em contextos de redemocratização, o desequilíbrio em favor da face pública tende a ser ainda mais acentuado, pois o partido ingressa no mercado eleitoral e nas arenas representativas antes de consolidar-se como uma organização minimamente autônoma em relação a seu entorno - sendo que o próprio contexto de transição incentiva os partidos a se lançarem no jogo parlamentar e governativo rapidamente, deixando pra trás eventuais posturas radicais. Essa sequência temporal favorece a concentração de recursos ao redor da face pública, deixando em segundo plano os dirigentes devotados à máquina. Nessa conjuntura, não há oportunidade nem necessidade de se construir uma organização mais autônoma (no sentido conferido por Panebianco) - ainda mais porque os meios de comunicação de massa já desempenhavam um papel central nos anos iniciais, possibilitando a formação de vínculos diretos entre candidatos

${ }^{2}$ Com o advento e disseminação da internet a partir dos anos 1990, os partidos voltariam a investir em canais próprios de comunicação, para atingir não tanto seus filiados mas sim os simpatizantes e eleitorado em geral (Margetts 2006).

${ }^{3}$ Pode-se citar ainda que uma análise sobre a trajetória profissional e política dos dirigentes teria algo a e eleitores (Van Biezen 2000) ${ }^{2}$.

Se os partidos brasileiros são agentes centrais ao menos no processo legislativo, na organização e sustentação dos governos, e na ocupação de espaços na burocracia pública (ou seja: nas funções procedimentais), conhecer os membros que comandam seus órgãos centrais se mostra um problema de pesquisa válido. A análise de suas elites dirigentes pode acrescentar bastante ao conhecimento sobre o partido, sua origem, sua transformação, seu relacionamento com as bancadas e governos, sua democracia interna e seus padrões de recrutamento e estruturas de oportunidade, apenas para ficar em alguns destaques ${ }^{3}$.

A fisionomia da elite dos partidos também possui implicações teóricas. Se comprovada empiricamente, a multiplicidade de perfis fragiliza modelos que 
contribuir acerca dos laços do partido com atores externos, como associações, sindicatos, movimentos sociais, grupos empresariais etc. enxergam os partidos como "super-atores" racionais, capazes de perseguir cargos, políticas ou outros objetivos de modo unívoco. Também prejudica a adoção do modelo analítico das três faces de Katz \& Mair (1995), já que o party central office (direção nacional) não poderia ser tomado como uma face unívoca, contraposta ao party on the ground (bases do partido) e ao party in public office (face pública, que engloba parlamentares e membros do governo, eleitos ou não). Colocando o problema sob outro ângulo, uma eventual homogeneidade no perfil da direção tampouco garantiria a validade do modelo, já que o domínio completo e contínuo das instâncias centrais pelos parlamentares e/ou membros com cargos no governo apagaria as distinções entre direção e face pública.

Em artigo recente, Katz (2014) mantém a distinção entre as três faces como instrumento analítico, para especular sobre as conexões e sentidos dos vínculos principal-agente em governos partidários, diferenciando entre o modelo duvergeriano de massa e o modelo downsiano de partido. Nesse diapasão, a direção pode ser encarada (partido de massa) como principal da face pública e agente das bases do partido (por sua vez imbricadas com um segmento específico do eleitorado, principal originário), que também atuam como principal da face pública. Mas a direção também pode ser tomada (partido downsiano) como agente da face pública (ajudando-a a lidar com um eleitorado disperso que atua como principal originário) e principal em relação às bases, que têm a face pública como outro principal. Face pública e direção partidária se veem confrontadas com a possibilidade de terem, cada uma, ao menos dois principais diferentes (base do partido, segmento do eleitorado, eleitorado disperso, além de um ao outro), com interesses que podem ser inconciliáveis. Ainda que com outras palavras, trata-se de dilema já apontado por Michels (2001, pp. 77, 176-180, 237-238) há um século, quando discutia (e condenava) a substituição dos laços de responsividade dos políticos eleitos e dirigentes, da base organizada do partido (e sua classe gardée) rumo ao eleitorado disperso (e com alvo no eleitor mediano, completaria Downs).

Essa tensão - que repercute na formação e condução de governos (multi)partidários, em termos da amplitude e foco das políticas, por exemplo - pode se mostrar mais aparente do que real, a depender do perfil da direção partidária. Invertendo o sentido das conexões de Katz (2014), uma direção dominada por parlamentares e membros do governo (como é a tendência dos partidos contemporâneos, conforme Katz \& Mair 2009) tende a atuar como instância de apoio à face pública (principalmente se o partido comanda o governo). Essa situação não só torna inócua a distinção analítica entre as duas faces como simplifica a questão de "quem manda": em última instância, todos precisam batalhar por conquistar, manter e ampliar o apoio da maior parte do eleitorado disperso (ainda mais com democracias intrapartidárias frágeis, e num contexto de diluição de clivagens tradicionais, multiplicidade de identidades e demandas etc.). $\mathrm{O}$ resultado será um governo (multi)partidário em que as políticas convergem rumo ao eleitor mediano, independentemente do partido vencedor.

De qualquer modo, essa eventual sobreposição entre as duas faces pode potencializar um dos papéis desempenhados pelas direções partidárias nacionais, especialmente quando o partido comanda o governo em sistemas presidencialistas. Na medida em que Executivo e Legislativo são constitucionalmente independentes, as instâncias centrais das legendas podem atuar como um dos espaços mais importantes de negociação e promoção de coesão entre bancadas, Presidência da República (e toda a máquina a sua disposição), e o restante do corpo partidário. Esse papel das comissões executivas, levantado por V.O. Key (1962, pp. 964-966), leva a encarar a falta de coesão na direção nacional como algo paradoxalmente positivo para uma coesão maior, envolvendo partido, bancadas e governo: a multiplicidade de perfis emerge como reflexo desses agrupamentos e interesses. Ganha destaque, aqui, o papel representado pelo 
${ }^{4}$ Na formulação de V.O. Key (1962, p. 260), o partido pode ser desagregado em quatro faces: (i) partido no eleitorado (que inclui os filiados do partido ou, no caso americano, em que não há adesão formal, os eleitores alistados e simpatizantes); (ii) direção (dirigentes e funcionários do partido); (iii) bancadas; (iv) partido no governo (apenas quando o partido comanda ou integra o governo).

\section{Recortes e metodologia}

sistema de patronagem, em que as direções partidárias exercem a função de intermediação entre clientes ávidos por cargos e membros do partido que controlam tais postos na máquina pública. A presença de beneficiados pela patronagem nas cúpulas é encarada como parte dessa estratégia de coesão e acomodação de tensões entre direção, parlamentares e governo. Nas palavras de Key (idem, p. 560), a patronagem tem o condão de "[...] integrar la actividad de individuos que no están unidos por otra clase de vínculos". A presença dos political appointees pode constituir uma ponte de coesão tanto em nível nacionalnacional (executiva nacional, governo federal e membros do Congresso Nacional), como na integração vertical entre cúpula nacional e seções, parlamentares e administrações subnacionais (idem, pp. 484-512, 534-535; Lawson 1976, pp. 157-158, 170).

As considerações acima não impedem o "uso moderado" do modelo das três faces como uma ferramenta analítica. Ao longo do artigo, o termo face pública é empregado para designar o conjunto de membros do partido que ocupam cargos públicos, eletivos ou não, em todas as esferas. A desagregação dos clientes da patronagem nas categorias "governo federal" versus "outros cargos" se dá não apenas como recurso operacional para o teste de uma das hipóteses (a terceira). Trata-se também de atenção à preocupação de Key (1962, p. 260) em separar os grupos no legislativo dos grupos no executivo, nos momentos em que o partido comanda (ou integra) o governo ${ }^{4}$.

Além dessa discussão inicial, o artigo conta com outras cinco seções. $\mathrm{Na}$ próxima são apresentados e justificados os recortes e estratégias metodológicas empregados, para na sequência discutirem-se alguns dos principais aspectos institucionais intrapartidários que podem influenciar os níveis de participação da face pública nas cúpulas partidárias. A seção seguinte constitui o núcleo do artigo. Visando testar as hipóteses, são avaliadas, na sequência, (i) a localização ideológica; (ii) a força eleitoral/parlamentar; (iii) a participação no governo e a (iv) origem do partido como fatores explicativos dos padrões e diferenças identificados na análise comparada dos dados. Ao final da seção, um modelo explicativo integrado sugere a origem partidária (interna ou não) como principal variável explicativa para o peso da face pública nas executivas. A seção seguinte vai além dos números para apontar alguns nomes de dirigentes que se destacam nas cúpulas partidárias, sublinhando que o núcleo decisório das máquinas (secretaria geral, de finanças etc.) pode apresentar uma fisionomia um pouco distinta das executivas como um todo, em termos da presença de dirigentes com perfil mais burocrático, e com altos níveis de estabilidade. A discussão final retoma algumas das implicações políticas e teóricas abordadas nesta introdução, sugerindo que por trás da presença dos mandatários nas executivas (que não pode ser confundida com domínio monolítico e homogêneo) encontra-se a necessidade de articulação e coesão entre distintos elementos do corpo partidário. Os apêndices trazem os resultados completos dos testes estatísticos realizados, bem como as tabelas com os dados utilizados na análise, totalmente desagregados.

O recorte engloba os maiores partidos do atual quadro democrático: PFL/DEM, PDS/PPB/PP, PMDB, PSDB, PT, PSB e PDT. O recorte temporal abrange da fundação do partido - incluindo sua comissão diretora nacional provisória (CDNP), embrião da executiva nacional - até as instâncias formadas em 2013. No caso do PP, foram considerados como seus antecessores diretos o PDS (de 1980 a 1992), o PPR (fusão entre PDS e PDC em 1993), e o PPB (fusão entre PPR e PP em 1995, que alteraria sua nomenclatura para PP em 2003). Juntos, os sete partidos conquistaram quase $80 \%$ das cadeiras em disputa no 
${ }^{5}$ As informações que o TSE possui sobre o PTB estão bastante incompletas, e não conseguimos encontrar dados mais completos e confiáveis sobre suas executivas nacionais em outras fontes. Sendo assim, o partido foi excluído da análise.

${ }^{6}$ Os diretórios nacionais são eleitos pelo encontro, congresso ou convenção nacional do partido. A partir de 2001, o diretório nacional do PT passou a ser escolhido de modo direto, pelo conjunto de filiados. À exceção do presidente nacional - também eleito pelo voto direto dos filiados - os demais membros da executiva petista continuaram sendo indicados a partir de negociações no âmbito restrito do diretório.

\footnotetext{
${ }^{7}$ PDT e PP também possuem conselhos nacionais, formados quase exclusivamente por notáveis. No entanto, esses órgãos têm poderes apenas consultivos, mais reduzidos do que nos demais partidos citados.
}

\footnotetext{
${ }^{8}$ Os dados do PMDB foram completados com a ajuda de Fernando Bizzarro, a quem agradeço.
}

Senado e $71 \%$ das cadeiras da Câmara em 2010, e cerca de $70 \%$ das prefeituras nas eleições de $2012^{5}$.

As instâncias analisadas foram as comissões executivas nacionais, indicadas a cada dois, três, ou quatro anos pelos respectivos diretórios nacionais ${ }^{6}$. Como sublinha Panebianco (1995, pp. 367-368), há uma forte tendência para que as instâncias maiores e deliberativas, que enfrentam dificuldades de agenda, de coordenação e ação coletiva, transformem-se em minicongressos partidários, que apenas formalizam, ratificam e fiscalizam as decisões tomadas pelos órgãos executivos, mais enxutos e coesos, com capacidade maior de decisão e coordenação. No Brasil não é diferente: em praticamente todos os grandes partidos as executivas subverteram o papel que lhes é conferido pelos estatutos, convertendo-se nas instâncias decisórias centrais nos períodos entre as convenções e congressos partidários. Embora uma dose de efeitos não previstos ajude a explicar esses processos, reformas promovidas pelas elites partidárias (sobretudo no PFL/DEM e PSDB) também estão por trás desse fortalecimento das executivas vis-à-vis os diretórios nas estruturas decisórias internas.

Uma das novidades das últimas duas décadas nessa seara diz respeito à criação e fortalecimento, no PMDB, PSDB e PFL/DEM, de órgãos de cúpula compostos exclusivamente através de critérios de senioridade e proeminência política. Trata-se dos Conselhos Nacionais, formados pelos maiores caciques das siglas, quase todos na condição de membros natos: ex-presidentes da República, (ex)governadores, (ex)ministros, ex-presidentes do partido, a que se somam alguns poucos "notáveis" indicados pelo diretório ou convenção nacional (Ribeiro 2013a). Embora esses órgãos de cúpula estejam assumindo uma importância crescente na estrutura decisória frente às comissões executivas, a problemática de caracterização das elites dirigentes não se coloca para tais instâncias, pois o perfil de "líderes notáveis" já diz quase tudo (esse ponto é retomado mais adiante) $)^{7}$.

O primeiro desafio empírico foi obter as relações completas dos nomes dos dirigentes que integraram cada composição da executiva nacional de cada um dos partidos. Os sites dos partidos costumam apresentar apenas as composições atuais, enquanto o site do TSE oferece as relações nominais a partir de 20062007. Assim, o grosso dos dados foi obtido em pesquisa de campo no TSE. A despeito da obrigatoriedade de registro das instâncias dirigentes junto à Justiça Eleitoral, há muitas lacunas nesses dados, principalmente em relação a instâncias formadas entre o final da década de oitenta e início dos anos noventa. Tentamos preencher esses claros junto aos próprios partidos, tanto em suas páginas oficiais na internet (e de suas fundações/institutos de pesquisa), como por meio de contatos diretos com dirigentes. Certas composições também foram garimpadas em documentos dispersos das legendas (como estatutos, resoluções, plataformas etc.) e em estudos monográficos sobre os partidos. Mesmo assim, conseguimos os dados completos apenas para PT, PSDB, PMDB e PFL/DEM, cobrindo todas as executivas nacionais já constituídas desde a criação desses partidos ${ }^{8}$.

Considerou-se sempre a composição original da executiva, no momento de eleição ou posse da instância (as listas de nomes nem sempre trazem a data exata de formação da instância). Desconsideramos as alterações pontuais feitas na executiva durante a gestão, com a substituição de membros por motivos diversos (renúncia, doença, convite para assumir cargo público etc.). Tal regra foi abandonada apenas nos casos extraordinários em que se deu uma alteração radical da instância antes do momento previsto para a renovação - como a executiva nacional do PT reconstituída em 2003, devido à saída de vários dirigentes para assumir cargos no governo Lula, ou a executiva formada pelo PFL/DEM no período de "refundação" da sigla. Foram considerados todos os dirigentes 
titulares, com cargo específico na máquina (tesoureiro, secretário-geral etc.) e sem cargo (os chamados vogais), além dos líderes das bancadas na Câmara e Senado, membros natos das instâncias em todos os partidos. Ficaram fora do universo os suplentes da executiva e os integrantes sem poder de voto - como é o caso, em alguns partidos, dos representantes de órgãos temáticos (mulheres, juventude etc.), que têm assento assegurado na instância, mas apenas com direito à voz.

Levando em conta tais critérios, o número de membros em cada formação (gestão) da executiva nacional variou bastante entre os partidos. Como se vê nas tabelas do Apêndice 2, para todos eles a tendência, ao longo do tempo, foi de aumento da instância. A executiva nacional do PT variou entre 11 e 22 membros, em cada uma das 16 composições diferentes formadas entre 1980 e 2013; a executiva do PFL/DEM variou entre 11 e 45 membros, em 13 formações de 1985 a 2011, enquanto a do PSDB, entre 11 e 33 dirigentes também em 13 formações, de 1988 a 2013. Já a executiva do PMDB variou entre 11 e 19 dirigentes, em 16 formações de 1980 a 2013. Há lacunas nos dados dos demais partidos. Considerando apenas as composições que conseguimos coletar, o PDS/PPB/PP teve entre 11 e 73 membros em cada composição da executiva, nas 12 coletadas entre 1980 e 2009; o PDT, entre dez e 23 integrantes, em nove formações de 1980 a 2013, enquanto as 12 executivas do PSB variaram entre oito e 34 membros, de 1985 a 2011. No total, 91 comissões executivas foram avaliadas.

Tendo sempre como referência a data (ao menos aproximada) em que a executiva tomou posse, classificamos cada dirigente em apenas uma das seguintes categorias: (i) mandatário eleito: ocupante de cargo eletivo executivo ou legislativo - vereador, deputado estadual/federal, senador, (vice)prefeito, (vice)governador, (vice)presidente; (ii) ex-mandatário: ex-ocupante de algum desses cargos executivos ou legislativos; (iii) ocupante de cargo não eletivo no governo federal: ministro, secretário, assessor, dirigente de empresa estatal etc.; (iv) ocupante de outros cargos não eletivos: comissionados em cargos municipais/estaduais, assessor parlamentar de todos os níveis etc.; (v) ex-ocupante de qualquer cargo não eletivo; (vi) sem histórico de cargos, eletivos ou de confiança.

Frente à importância do fenômeno da patronagem partidária para as legendas brasileiras (cf. Meneguello 1998; Praça, Freitas \& Hoepers 2012), e a seu papel potencial como elemento de coesão entre diferentes alas do partido (Key 1962), incluímos os cargos de confiança na análise - expediente aplicado em outros contextos principalmente para avaliar a presença de ministros nas cúpulas partidárias (Van Biezen 2000). Por outro lado, a participação nas instâncias muitas vezes constitui uma estratégia para assegurar a presença na mídia e/ou o espaço político (na sigla, região etc.), por parte de políticos derrotados ou com mandato encerrado. Por essa razão, também ex-mandatários e ex-ocupantes de cargos de confiança foram contabilizados.

Um grande número de dirigentes poderia ser classificado em mais de uma categoria - alguém que era deputado federal no momento de formação da executiva, mas que já tinha sido prefeito e deputado estadual, um ministro que se licenciou do mandato de deputado federal, um deputado estadual que já havia ocupado cargo de confiança municipal etc. A regra fundamental para classificar o dirigente foi: o cargo ocupado por ele no momento exato de formação da executiva. Em alguns casos, o indivíduo não ocupava um cargo naquele momento, mas era ex-mandatário eletivo e ex-ocupante de cargo de confiança. Nesses casos, considerou-se o cargo mais recente à época de constituição da executiva, exceto nos casos em que havia grande disparidade em relação à importância do cargo (como alguém que era ex-vereador e ex-ministro, e que 
foi classificado a partir desse cargo mais relevante, independente da ordem de datas entre eles). De qualquer forma, a resolução desses casos ambíguos acarretou diversas decisões de cunho às vezes subjetivo, mas que têm pouco impacto no resultado final.

O segundo desafio empírico foi a coleta de informações acerca das trajetórias político-profissionais de centenas de dirigentes, para traçar o perfil das elites partidárias brasileiras. As fontes principais dessa pesquisa foram: sites da Câmara, do Senado e de algumas Assembleias Legislativas; Dicionário Histórico-Biográfico Brasileiro (FGV-CPDOC); sites pessoais dos políticos; jornais locais e regionais (para dirigentes menos conhecidos). Se as informações relativas à ocupação de cargos eletivos estão relativamente bem cobertas com tais fontes, a dificuldade é muito maior na obtenção de dados precisos sobre a ocupação de secretarias municipais e estaduais nos anos 1980 e 1990, de postos em autarquias de todos os níveis etc. Assim, as categorias de ocupantes e ex-ocupantes de cargos de confiança estão possivelmente subestimadas, enquanto a categoria "sem histórico" pode estar acima do real. Portanto, o peso da face pública nas executivas é, provavelmente, maior que o apontado.

\section{Condicionantes institucionais}

${ }^{9}$ Estatuto do PDT (1999, art. 57).

${ }^{10}$ Estatuto do PMDB (2007, art. 19); Estatuto do PMDB (2013, art. 19); Código de Ética do PT $\left(2009\right.$, art. $\left.8^{\circ}\right)$. Antes disso, os estatutos do PT só colocavam restrições à participação concomitante em mais de uma executiva (restrição comum em outros partidos), e à permanência do dirigente por muitos mandatos seguidos na mesma instância.
A Lei Orgânica dos Partidos Políticos (LOPP, Lei n. 5682/1971), que regulava detalhadamente o arcabouço interno das legendas, assegurava a participação dos líderes das bancadas na Câmara e no Senado nas executivas nacionais dos partidos. Com a implantação da nova legislação em 1995 (Lei N. 9096), que concedeu autonomia organizativa aos partidos, essa obrigatoriedade foi derrubada. No entanto, os líderes das bancadas conservaram seu status de membros natos de diretórios e executivas em todos os partidos analisados, sendo que o PDT garante a eles a participação inclusive em uma "comissão permanente", composta por apenas sete membros, e responsável pela gestão cotidiana do partido sem a necessidade de convocar reuniões da executiva ${ }^{9}$.

Nenhuma das principais legendas coloca restrições estatutárias à presença de parlamentares nas executivas. Como herança institucional da LOPP (art. 26), alguns partidos restringiam a participação do presidente e vice-presidente da República, dos ministros, governadores e vice-governadores, dos secretários estaduais, e dos prefeitos e vice-prefeitos. Essa restrição foi derrubada pela maioria dos partidos nos estatutos de 1995-1996, no processo de adaptação ao novo contexto institucional. Apenas o PMDB conservou o veto (não muito respeitado) à participação do presidente da República, ministros, governadores, secretários estaduais e secretários municipais nas executivas. Uma reforma estatutária promovida em 2013 manteve a inelegibilidade apenas do presidente e dos governadores (além de prefeitos e vice-prefeitos, no tocante às executivas locais). Já o PT aprovou, em 2009, um Código de Ética que instituiu a proibição de que ocupantes de postos públicos, eletivos ou de confiança, integrem a comissão executiva do mesmo nível federativo do cargo - o que permite a participação de senadores e deputados federais na executiva nacional, segundo entendimento do partido ${ }^{10}$.

Além da ausência de restrições, a participação de parlamentares e outros mandatários eleitos nas cúpulas partidárias também é impulsionada pelas regras de composição das convenções nacionais (e subnacionais), também herdadas da LOPP e que foram pouco alteradas após 1995 - possivelmente porque atendem aos interesses da face pública das legendas. Com a exceção do PT, cujos encontros nacionais são mais representativos da base, nos demais partidos os critérios de participação nas convenções privilegiam os detentores de mandatos eletivos (especialmente parlamentares) e os membros do diretório nacional (o que já inclui muitos mandatários), conferindo a todos o status de membros 
11 Restringindo a já parca representatividade que era estipulada pela LOPP, a partir de 1996 o PDT transferiu das convenções para os diretórios a competência de eleger os delegados à convenção superior, e conferiu ao diretório e executiva nacionais a prerrogativa de fixar, de modo ad hoc, o tamanho de cada delegação estadual para a convenção nacional (Estatuto do PDT, 1996).

12 No PP, o voto cumulativo nos diretórios só é permitido no processo de eleição das executivas; nas convenções do PDT, o acúmulo só pode chegar a dois votos.

13 Estatuto do PFL (2003, art. 55); Estatuto do DEM (2007, art. 57); Estatuto do PSDB (1999, art. 64); Estatuto do PSDB (2003, art. 64). $\operatorname{natos}^{11}$. Potencializando o peso dos políticos eleitos, PMDB, PP, PFL/DEM e PDT permitem o voto cumulativo - quando o indivíduo é convencional por mais de uma categoria: é deputado e delegado do estado, é senador, delegado e membro do diretório etc. - sendo que os dois primeiros liberam o mesmo expediente inclusive para as deliberações dos diretórios ${ }^{12}$. Controlando a convenção nacional, a face pública do partido domina a eleição do diretório, que será responsável pela formação da executiva (Ribeiro 2013a).

Livres das amarras da LOPP, e dominando os principais órgãos deliberativos, os dirigentes partidários poderiam ter promovido reformas radicais na composição das principais instâncias decisórias, assegurando espaço cativo para mandatários e ex-mandatários. No entanto, cinco das sete legendas mantiveram apenas os líderes das bancadas na Câmara e Senado como membros natos das executivas nacionais; e o aumento na quantidade total de dirigentes da instância em todos os partidos (com destaque para o PP, cuja executiva hoje supera os 70 membros) fez o peso dos natos diminuir ao longo do tempo.

Somente PFL/DEM e PSDB promoveram alterações substantivas nessa seara, incluindo nas executivas nacionais diversos membros natos com critérios de senioridade e proeminência política. Na reforma estatutária de 2003, os antigos pefelistas promoveram à categoria de membros natos da executiva nacional os ex-presidentes do partido, o presidente do Conselho Consultivo, os líderes de governo, de maioria ou minoria, e os integrantes das mesas diretoras das duas casas do Congresso; somados aos líderes das bancadas, esses natos passaram a representar cerca de um terço do total de membros. Em 2007 foram incluídos os ex-presidentes do Instituto Tancredo Neves e o presidente do Fórum dos deputados estaduais, fazendo a proporção de natos atingir aproximadamente metade do total. No estatuto aprovado em 1999 os líderes das bancadas tucanas no Congresso ganharam a companhia do presidente do Instituto Teotônio Vilela e do presidente de honra do partido (FHC) como membros natos da executiva nacional; em 2003 os ex-presidentes da sigla também foram alçados à categoria, que passou a representar cerca de um quarto do órgão ${ }^{13}$. Tais reformas, somadas ao declínio eleitoral a partir de 2003 (mais em relação ao PFL/DEM), explicam boa parte do aumento do peso de ex-ocupantes de cargos eletivos nas cúpulas dos dois partidos nos últimos anos.

Por fim, vale ressaltar algumas especificidades do arcabouço institucional do PT. Só o partido de Lula possui uma elevada institucionalização dos conflitos internos, com um sistema de disputa pelos cargos na máquina formalizado e competitivo, girando ao redor das tendências - antes e após a implantação das eleições diretas em 2001. Esse sistema pressiona por uma maior rotatividade nas instâncias decisórias, ao mesmo tempo em que demanda maiores graus de envolvimento e dedicação dos militantes que desejam ocupar postos dirigentes o que pode refrear a participação de ocupantes de cargos legislativos e executivos. Apenas o PT conformou, ao longo do tempo, um claro padrão de integração vertical no recrutamento de suas elites, com canais ascendentes na estrutura de oportunidades que privilegiam a ascensão de quadros "nascidos" e formados no próprio partido (Ribeiro 2010). Enquanto os altos escalões da hierarquia petista são praticamente impermeáveis a elementos estranhos à máquina, as demais legendas se encontram mais abertas a padrões horizontais de carreira - como verificado por Marenco \& Serna (2007) em relação às trajetórias dos deputados federais dos maiores partidos.

O PT também foi o primeiro partido a implantar uma cota de gênero em todas as instâncias partidárias (30\%, em 1993), abrindo espaço na executiva nacional para mulheres com menos experiência em esferas legislativas e executivas - já que a proporção de mulheres nessas esferas é bastante inferior ao patamar da cota. O PSB possui, desde 2005 , cota de $30 \%$ para os diretórios, mas 
${ }^{14}$ Estatuto do PSB (2005, art. 22); Estatuto do PDT (1996, art. 82); Estatuto do PDT (1999, arts. 26; 83). A $11^{\text {a }}$ Convenção Nacional do PSDB (2013) implantou a cota de gênero de $30 \%$ nas chapas para os diretórios e delegações de todos os níveis - o que não significa que a cota será respeitada na formação do diretório ou da executiva (Estatuto do PSDB, 2013, art. 25). Apenas três mulheres integram a executiva nacional tucana eleita em 2013. não para as executivas. Já o PDT reservava às mulheres um quinto dos nomes nas chapas para disputa dos diretórios; a partir de 1999, o estatuto do partido estabelece a cota de $30 \%$ na composição final de todos os órgãos dirigentes - o que nem de longe é cumprido na executiva nacional, que conta com apenas duas ou três mulheres em cada formação ${ }^{14}$. Assim, entre os sete partidos, apenas o PT garante um espaço efetivo às mulheres nas executivas, o que tem se traduzido na presença frequente na cúpula nacional de militantes com perfil mais ligado aos movimentos sociais (feministas, de combate à discriminação/violência etc.).

As diferenças institucionais do PT aumentaram após as decisões de seu $4^{\circ}$ Congresso Nacional (2011), que instituíram a paridade de gênero em todas as instâncias, delegações e cargos com funções específicas (secretarias) no partido, e a cota de $20 \%$ de jovens (menos de 30 anos) em todos os órgãos ${ }^{15}$. Aplicadas já na renovação das direções em 2013, tais regras resultaram em uma executiva nacional com um perfil menos parlamentarizado (ver Apêndice 2), e podem aumentar a distância do PT frente a seus concorrentes nesses quesitos. Se as especificidades da estrutura petista não impediram o aumento dos níveis de parlamentarização desde 1980, ainda são suficientes para marcar a diferença do partido: o PT de 2014, ainda que bem distinto do PT dos anos 1980, continua sendo uma "anomalia" no quadro político brasileiro (Ribeiro 2014).

\section{Face pública e seus determinantes em perspectiva comparada}

${ }^{15}$ Estatuto do PT (2012, art. 22).

${ }^{16}$ Utilizamos a escala calculada por Tarouco \& Madeira (2013) a partir dos dados de Power \& Zucco (2011), que estimam o posicionamento ideológico com base em entrevistas com parlamentares. Índices: PT = 3,6; PSB = 3,7; $\mathrm{PDT}=4,0 ; \mathrm{PSDB}=5,8$; $\mathrm{PMDB}=5,9 ; \mathrm{PP}=7,6 ; \mathrm{e}$ $\mathrm{DEM}=7,8$. Essa escala tem altos níveis de correspondência com outras que se valem de métodos alternativos (cf. Tarouco \& Madeira 2013).

${ }^{17} \mathrm{O}$ resultado seria pouco modificado se levássemos em conta conceituações alternativas de face pública, considerando apenas os mandatários eleitos, ou os mandatários e ex-mandatários, ou a soma entre mandatários, ex-mandatários, e (ex)ocupantes de cargos de confiança etc.
O Gráfico 1 (as tabelas desagregadas estão em Apêndice 2) representa a participação média dos ocupantes de cargos eletivos e de confiança nas executivas nacionais, situando cada partido numa escala ideológica que vai de 1 (extrema esquerda) a 10 (extrema direita $)^{16}$. Nota-se certa correspondência com os campos ideológicos: quanto mais à direita na escala, maior tende a ser o peso da face pública nas executivas nacionais ${ }^{17}$.

PT, PSB e PDT possuem os menores índices de parlamentarização. Em média, menos de $40 \%$ dos integrantes de cada executiva são mandatários eleitos; acrescentando-se os ocupantes de cargos de confiança, não se chega à metade do órgão. O PSDB se situa em posição intermediária: suas executivas têm, em média, cerca de $70 \%$ de mandatários. Comparadas às instâncias do outro partido de centro (PMDB) e das legendas de direita (PFL/DEM e PP), as executivas tucanas contam com a participação maior de ex-mandatários, notadamente líderes históricos da sigla, e de ocupantes e ex-ocupantes de cargos de

Gráfico 1 - Ideologia e peso da face pública (ocupantes de cargos eletivos e de confiança)

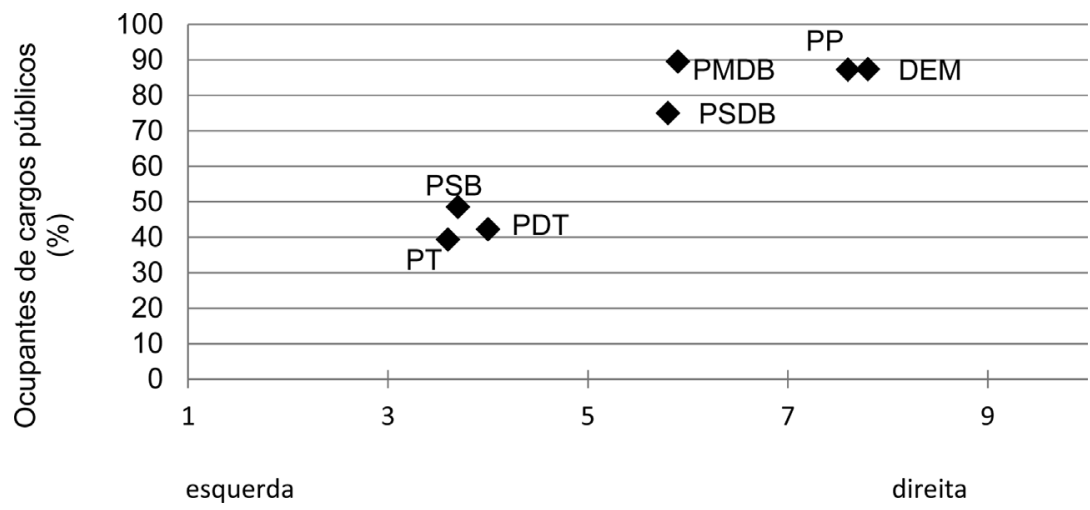

Nota: Foram somadas as médias históricas (todas as executivas) das categorias de mandatários e de ocupantes de cargos não eletivos.

Fonte: Elaborado a partir das tabelas do Apêndice 2 
confiança, com a ascensão na burocracia partidária de quadros importantes das gestões tucanas nos estados e do governo FHC. O partido também destoa pela maior participação de governadores, o que foge ao padrão parlamentar dos mandatários dos demais partidos. PFL/DEM, PP e PMDB possuem um nítido perfil de partidos parlamentares: as executivas nacionais são dominadas por ocupantes de cargos eletivos (média histórica superior a 80\%), com alguma presença de ex-mandatários e a participação residual das demais categorias. Aliás, a lógica eleitoral determina grande parte do fluxo entre mandatários e ex-mandatários nas executivas dos sete partidos: muitos deixam o órgão ao assumir cargos públicos, enquanto outros recebem postos na máquina partidária após derrotas eleitorais.

A presença de mandatários e ex-mandatários nas executivas petistas aumenta na medida em que o partido avança eleitoralmente, sobretudo nos anos noventa (ver Apêndice 2). No entanto, vale destacar que o partido conta, desde sua formação mais embrionária (a comissão diretora nacional provisória, de 1980), com a presença de parlamentares em exercício do mandato. No início do governo Lula há um refluxo na presença de ocupantes de cargos eletivos: vários políticos deixaram a cúpula da sigla para assumir cargos no governo federal, deixando o PT sob o comando de dirigentes de perfil burocrático, que tinham um longo histórico de dedicação exclusiva às máquinas partidária e sindical (e que seriam derrubados pelos escândalos de 2005-2006). A principal diferença do PT em relação a PSB e PDT reside na presença bem maior de dirigentes sem qualquer histórico de ocupação de cargos públicos, eletivos ou comissionados (Gráfico 2) - espaço ocupado nas outras legendas de esquerda por ocupantes e ex-ocupantes de cargos de confiança, e também por ex-mandatários eletivos, no caso do PDT.

Os resultados do teste ANOVA demonstram que existem diferenças significativas nas médias de participação da face pública quando os partidos são divididos entre os três campos ideológicos (ver o Apêndice 1). No entanto, embora o PSDB "puxe" os valores do bloco de centro para uma posição mais intermediária, o Gráfico 3 e os testes post hoc e de subconjuntos homogêneos (ver o Apêndice 1) indicam que as legendas de centro e direita poderiam ser agrupadas em um mesmo conjunto: não há diferenças estatisticamente significativas entre os campos de centro e direita, mas apenas entre o bloco da esquerda e os demais (quando analisamos o peso da face pública).

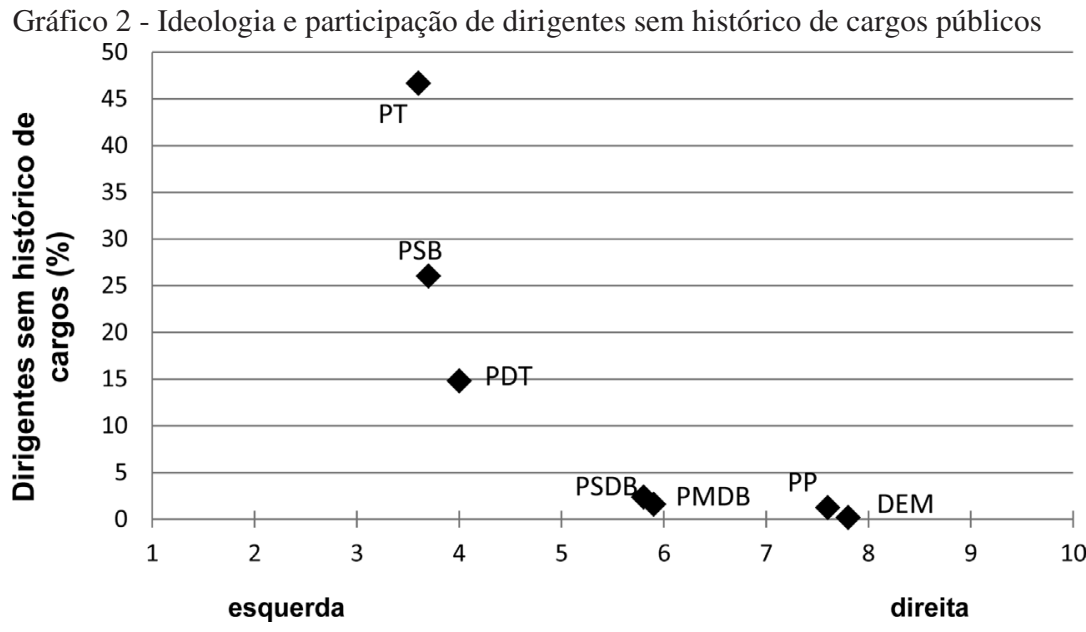

Nota: Foi considerada a média (todas as executivas) da categoria de dirigentes sem histórico de cargos.

Fonte: Elaborado a partir das tabelas do Apêndice 2 
Gráfico 3 - Campos ideológicos e peso da face pública (ocupantes de cargos eletivos e de confiança)

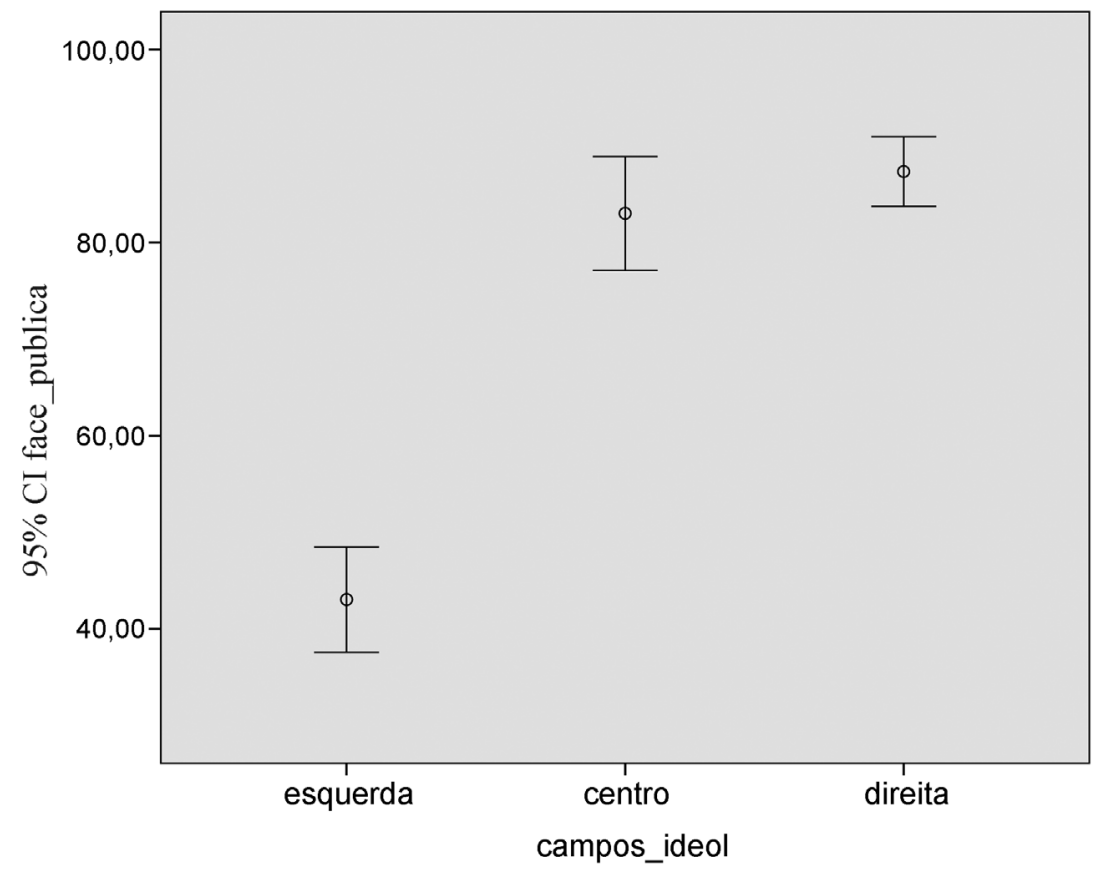

Nota: Foram somadas as médias históricas (todas as executivas) das categorias de mandatários e de ocupantes de cargos não eletivos. Esquerda: PT, PSB e PDT; Centro: PMDB e PSDB; Direita: PP e PFL/DEM.

Fonte: Elaborado a partir das tabelas do Apêndice 2

Especulou-se acima acerca da influência do desempenho eleitoral sobre a participação da face pública nas executivas (aumento de mandatários na cúpula petista e o efeito inverso no PSDB e DEM a partir de 2003). O Gráfico 4 relaciona a participação percentual dos ocupantes de cargos eletivos em cada executiva nacional com o tamanho da bancada (\% de cadeiras) obtida pelo respectivo partido na eleição para a Câmara imediatamente anterior à formação da executiva (considerando a bancada uma variável proxy da força eleitoral do partido, como poderiam ser as quantidades de prefeitos, de deputados estaduais etc.). Como se vê, há uma elevada correlação entre os dois indicadores: quanto maior a força eleitoral/parlamentar do partido, mais parlamentares se fazem presentes no principal órgão partidário.

Pode-se argumentar que a força eleitoral/parlamentar não é uma variável tão relevante quanto à participação no governo. A hipótese tem validade para o caso brasileiro. Com a exceção do PP, cujos índices permanecem estáveis (e elevados), nos demais partidos o peso total da face pública (mandatários eleitos e ocupantes de cargos de confiança) é maior nas executivas que são formadas quando o partido integra a coalizão de apoio ao governo federal, em comparação às instâncias constituídas nos períodos de oposição. O Teste T corrobora essa associação: as taxas médias de ocupantes de cargos públicos são significativamente distintas quando se comparam as executivas governistas e oposicionistas (ver Apêndice 1). Se o aumento na proporção de mandatários eleitos é responsável por parte desse processo, é outra categoria que se destaca: os ocupantes de cargos de confiança na administração federal representam uma parcela significativa dos membros das executivas que são constituídas quando o partido está no governo (Gráficos 5 e 6. Ver também os dois gráficos do Apêndice 1). 
Gráfico 4 - Bancada na Câmara e peso dos mandatários eleitos nas executivas

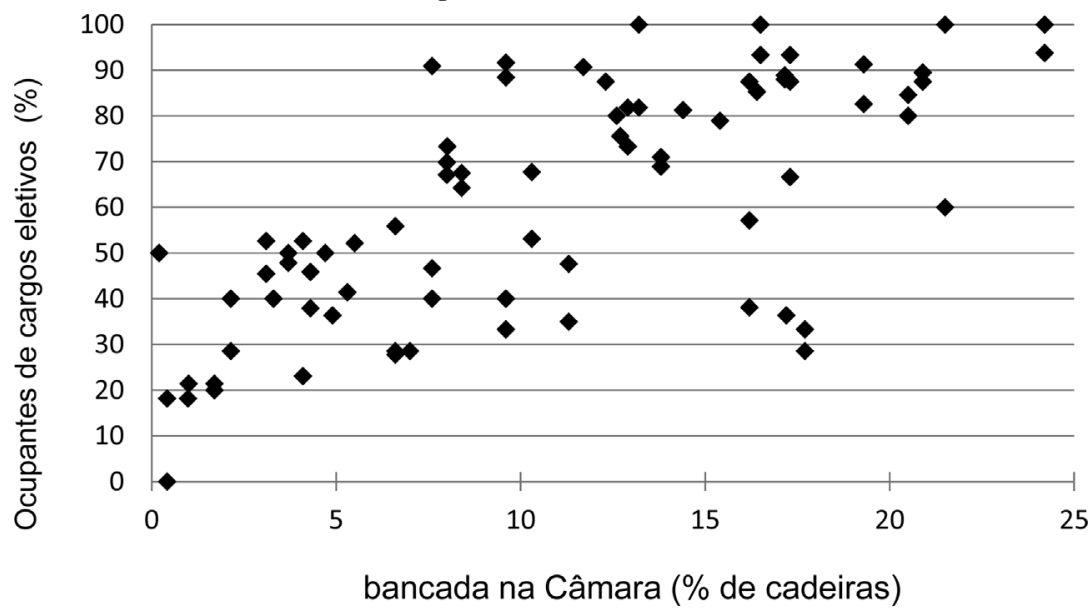

Nota: Foi considerada a participação percentual dos mandatários eleitos em cada executiva nacional de cada partido, relacionando esse valor à bancada obtida pelo partido na eleição imediatamente anterior para a Câmara dos Deputados. Para as executivas formadas antes das eleições de 1982, foram considerados os tamanhos efetivos de cada bancada no momento de formação da executiva. Para efeitos de clareza e diferenciação da grande maioria dos casos, foram excluídas 11 comissões executivas do gráfico (sete do PMDB e quatro do PDS/PP), formadas nos anos 1980 sob um padrão ainda bipartidário, quando as duas maiores bancadas oscilavam entre $30 \%$ e $55 \%$ das cadeiras. Assim, $\mathrm{N}=80$.

Fonte: Elaborado a partir das tabelas do Apêndice 2

O impacto da participação no governo sobre partidos recém-criados também se mostra uma hipótese consistente. As quatro executivas com os maiores índices de participação da face pública da história do PFL/DEM foram constituídas no período Sarney-Collor, entre 1986 e 1991 (índices variando entre $94 \%$ e $100 \%$, com média de $98 \%$ ). De modo análogo, as três executivas que

Gráfico 5 - Participação no governo e peso dos ocupantes de cargos de confiança no governo federal (\%): média por partido

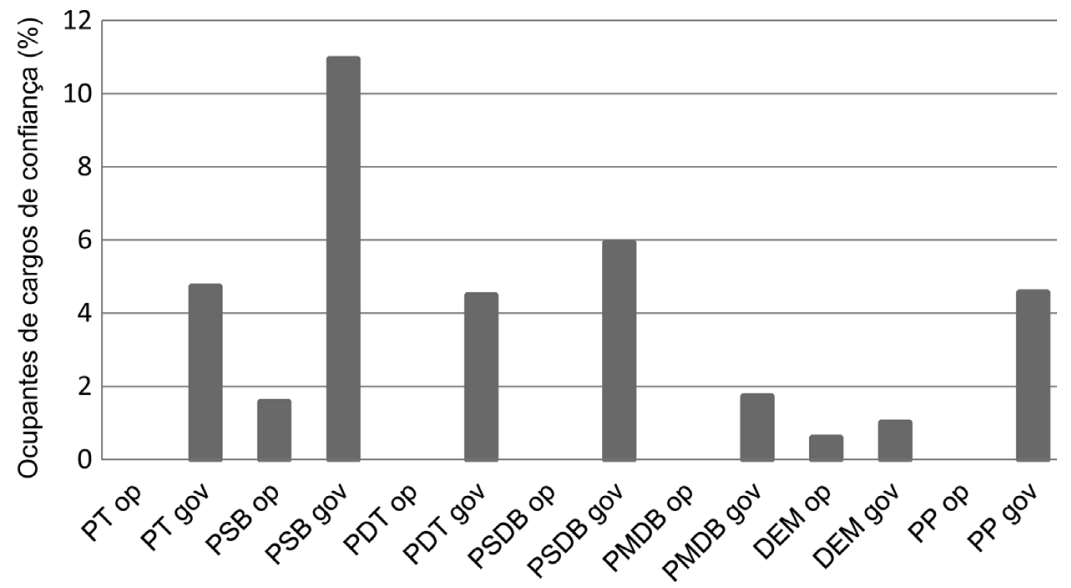

Nota: Foi calculada a média da participação percentual dos ocupantes de cargos de confiança no governo federal (ministérios, empresas e agências federais etc.) nas executivas formadas quando o partido integrava a coalizão de apoio ao governo federal; e o mesmo cálculo para as executivas constituídas quando o partido fazia parte da oposição. Os integrantes das coalizões governistas na Câmara foram coletados em Figueiredo e Limongi (2007).

Fonte: Elaborado a partir das tabelas do Apêndice 2 
Gráfico 6 - Dirigentes com cargos de confiança no governo federal (\%) nas executivas formadas no governo e nas executivas formadas na oposição (médias)

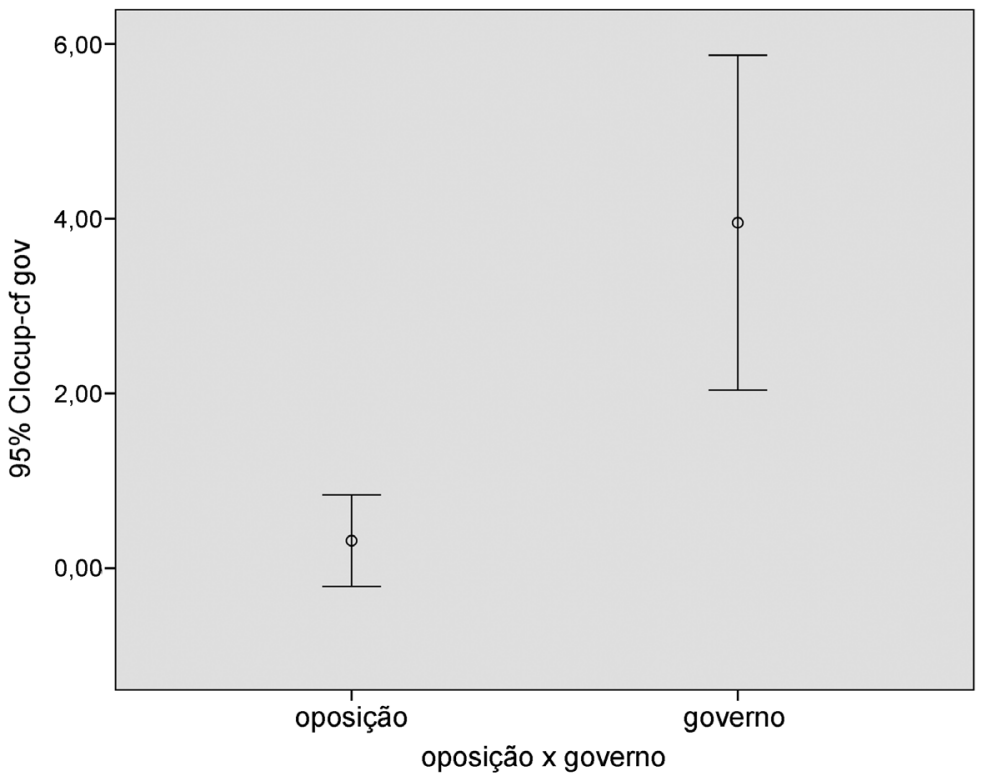

Nota: Foi calculada a média da participação percentual dos ocupantes de cargos de confiança no governo federal nas executivas formadas quando o respectivo partido integrava a coalizão de apoio ao governo federal $(\mathrm{N}=42)$; e o mesmo cálculo para as executivas constituídas quando o partido fazia parte da oposição $(\mathrm{N}=49)$. Os integrantes das coalizões governistas na Câmara foram coletados em Figueiredo e Limongi (2007).

Fonte: Elaborado a partir das tabelas do Apêndice 2

lideram esse ranking no caso do PSDB (média de 95\%) foram as formadas ao longo da era FHC, entre 1996 e 2001 (cf. Apêndice 2).

No tocante à origem do partido - se interna ou externa ao parlamento - os quatro partidos de centro e direita são casos típicos de agremiações criadas internamente, em processos de reacomodação das elites políticas; já o PT é o exemplo típico-ideal de fundação externa de um partido no Brasil. PSB e PDT podem ser considerados casos intermediários, na medida em que seus processos fundacionais envolveram mais políticos profissionais, sem que isso se traduzisse, no entanto, em bancadas expressivas na Câmara e Senado nos anos iniciais. Uma rápida olhada nas primeiras direções constituídas pelos partidos as comissões diretoras nacionais provisórias - confirma essas suposições. Apenas os partidos de esquerda contavam com dirigentes sem histórico de cargos públicos em suas comissões fundacionais, sendo que o PT possuía mais dirigentes com esse perfil (nove dos 11) do que PDT e PSB.

Assim como no caso dos campos ideológicos, o teste ANOVA (ver Apêndice 1) aponta para diferenças estatisticamente significativas no peso da face pública quando dividimos os partidos em três grupos: os de origem externa (PT), mista (PDT e PSB), e interna (os demais). No entanto, os testes post hoc e de subconjuntos novamente sugerem certa indistinção entre dois dos grupos partidos de origem externa e mista - com apenas um conjunto se diferenciando claramente em relação aos demais - as legendas de origem interna (ver Apêndice 1). O Gráfico 7 ilustra esses resultados.

Como o Gráfico 8 ilustra, existe uma sobreposição entre duas variáveis origem e campo ideológico - o que dificulta a determinação de qual delas possui o maior poder explicativo em relação ao perfil das cúpulas. Nota-se uma grande clivagem entre, de um lado, os três partidos de esquerda, com processos de 
Gráfico 7 - Origem do partido e peso da face pública (ocupantes de cargos eletivos e de confiança)

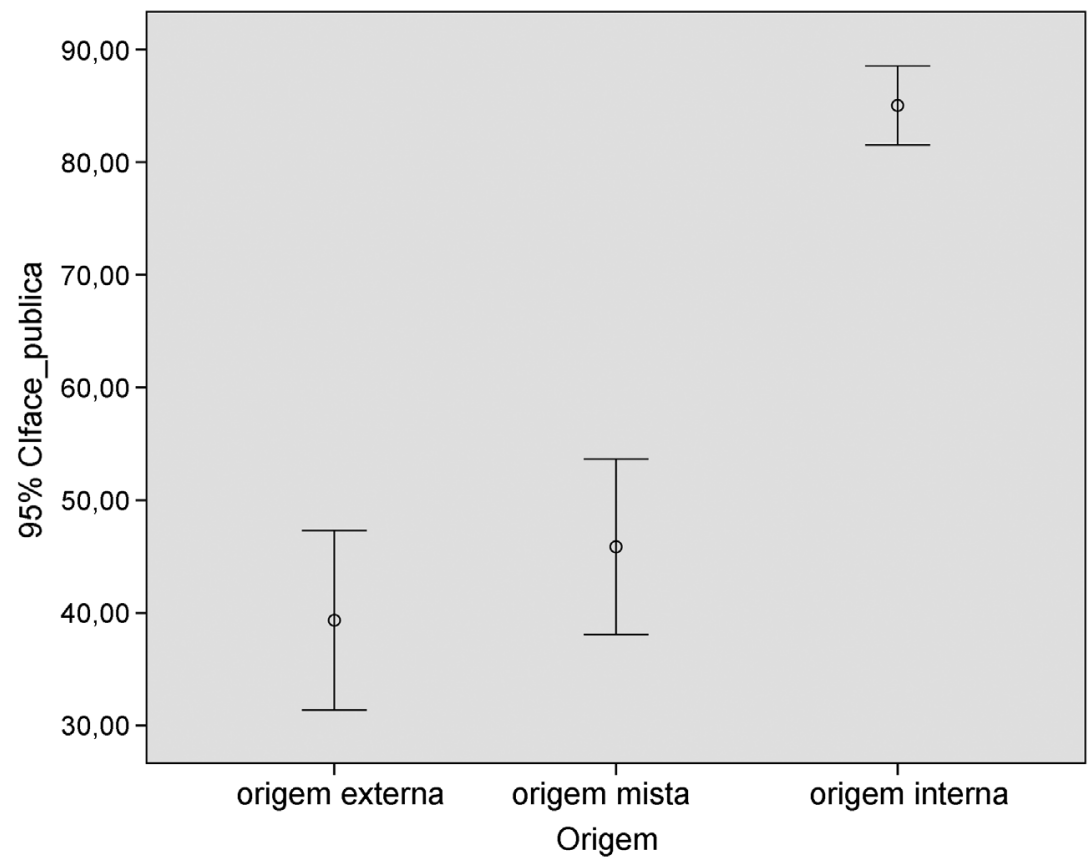

Nota: Foram somadas as médias históricas (todas as executivas) das categorias de mandatários e de ocupantes de cargos não eletivos. Origem externa: PT; mista: PSB e PDT; interna: PMDB, PSDB, PP e PFL/DEM.

Fonte: Elaborado a partir das tabelas do Apêndice 2.

fundação ao menos parcialmente apoiados em esferas exteriores aos aparelhos de Estado, e do outro lado os demais partidos, criados em processos internos ao legislativo e à classe política.

O peso que a face pública terá nas cúpulas partidárias parece ser influenciado pela ideologia, pela força eleitoral/parlamentar e pela participação do partido no governo. Entre as duas primeiras variáveis, a posição do partido na escala ideológica é a que possui os maiores coeficientes de correlação com o perfil da executiva: é superior a 0,72 em relação ao peso dos mandatários eleitos, da face pública total - ambos positivos - e dos dirigentes sem histórico de cargos - com associação inversa nesse caso (Tabela 1). Quanto mais à direita o partido, maior é a probabilidade de que sua executiva nacional seja dominada por ocupantes de cargos eletivos, e menos se encontram dirigentes sem histórico de cargos. Por outro lado, os partidos de esquerda tendem a abrigar mais ocupantes de cargos de confiança do que os partidos de centro e direita - embora a associação seja bem mais tênue nesse caso.

É razoável especular que o PT talvez seja responsável por grande parte da variação encontrada quando nos movemos para a esquerda do continuum ideológico. Pode-se falar em diferença da esquerda, ou apenas o PT é diferente? O PSDB também se destaca quando comparado aos demais partidos de centro e direita, que pouco se diferenciam entre si. Na construção de um modelo de regressão para mensurar a influência de cada variável na explicação do peso da face pública, incluiu-se uma variável dummy para o PT, e outra para o PSDB. Como origem do partido e pertencimento a um dos três campos ideológicos são variáveis que se sobrepõem, elas foram combinadas em uma única dummy: $0=$ esquerda e origem não interna; 1 = centro/direita e origem interna. 
Gráfico 8 - Origem, campo ideológico e peso da face pública (ocupantes de cargos eletivos e de confiança)

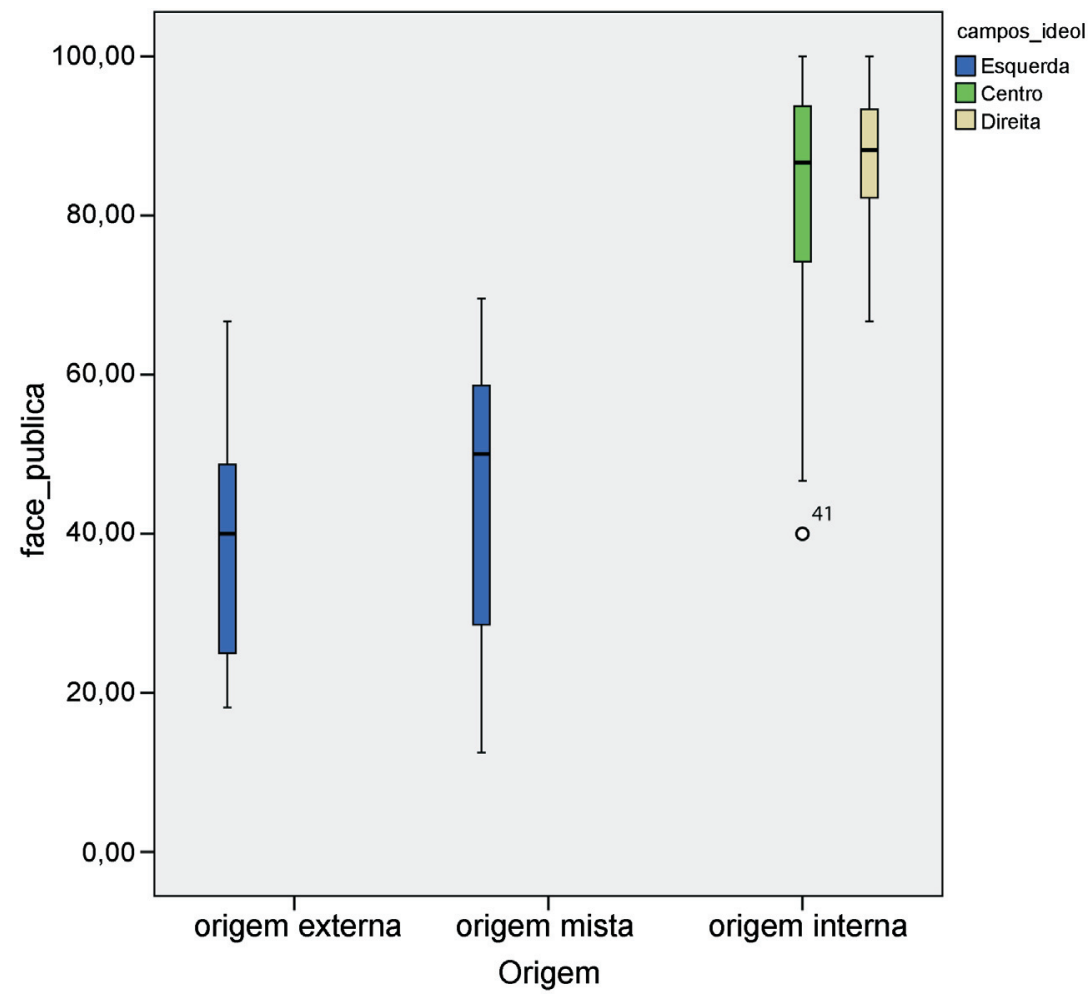

Nota: Foram somadas as médias históricas (todas as executivas) das categorias de mandatários e de ocupantes de cargos não eletivos.

Fonte: Elaborado a partir das tabelas do Apêndice 2

Assim, as seguintes variáveis foram consideradas: ideologia (escala de 1 a 10), tamanho da bancada, e as variáveis dummy origem/campo, PT, PSDB, e oposição x governo. Em todos os modelos testados, a variável origem/campo apresentou o maior poder explicativo. Com todas as variáveis em jogo (método stepwise), a escala ideológica se mostrou a mais frágil; e como era de se esperar, essa variável apresentou elevados índices de multicolinearidade com a variável origem/campo, demandando a exclusão de uma delas. Na comparação entre os dois modelos, o modelo com a variável origem/campo se mostrou com poder explicativo maior do que aquele que trazia a escala ideológica (e mais parcimonioso também). Os resultados desse modelo são resumidos na Tabela 2.

Consideradas em conjunto, três das variáveis independentes já conformam um modelo que dá conta de explicar a maior parte da variação no peso da face pública nas executivas nacionais. A variável origem/campo, que discrimina os partidos em dois grandes grupos, aparece como principal fator preditivo: sozinha, é capaz de explicar quase $70 \%$ das variações observadas (R quadrado $=$ 0,674). Em todos os modelos testados, a variável manteve-se como principal fator explicativo (valor beta sempre muito superior ao das demais variáveis). Comparando-se ao desempenho da variável escala ideológica, os resultados sugerem que a origem do partido - se interna ou não - possui mais importância na determinação do perfil das executivas nacionais do que sua localização no continuum esquerda-direita. Os partidos de centro e direita, embora distantes na escala (PSDB: 5,8; PMDB: 5,9; PP: 7,6; DEM: 7,8), possuem executivas com perfil semelhante, altamente parlamentarizadas, sendo difícil discriminar entre o centro e a direita. Apenas o PSDB se diferencia levemente entre as quatro legendas: como indicam os seus coeficientes, uma executiva tucana tende a ser 
Tabela 1 - Correlações entre ideologia, força parlamentar e peso da face pública

\begin{tabular}{llcc}
\hline & & Ideologia & $\begin{array}{c}\text { Força } \\
\text { parlamentar }\end{array}$ \\
\hline Mandatários eleitos & r & $\mathbf{0 , 8 1 0}(0,000)$ & $\mathbf{0 , 6 0 1}(0,000)$ \\
Ocupantes de cargos de confiança & r quadrado & 0,656 & 0,361 \\
& r quadrado & 0,086 & 0,006 \\
Face pública (mandatários+ocu- & r & $\mathbf{0 , 7 7 2}(0,000)$ & $\mathbf{0 , 6 0 6}(0,000)$ \\
pantes cargos de confiança) & r quadrado & 0,596 & 0,368 \\
Sem histórico de cargos públicos & r & $\mathbf{- 0 , 7 2 9}(0,000)$ & $-0,461(0,000)$ \\
& r quadrado & 0,532 & 0,213 \\
\hline
\end{tabular}

Fonte: elaboração própria, tomando cada formação de executiva como um caso ( $\mathrm{N}=91)$, e utilizando a correlação de Pearson. A significância está entre parênteses.

consistentemente distinta das executivas dos demais partidos de centro e direita, com vetor negativo (menos dirigentes com perfil de face pública). Já a variável PT não apresentou coeficientes tão significativos; assim, pode-se dizer que a origem não interna dos partidos de esquerda realmente possui um forte potencial explicativo no tocante ao peso da face pública. A não especificidade do PT é o resultado esperado se consideramos as médias gerais da face pública dos partidos de esquerda (39\% para o PT, 42\% para o PDT, 49\% para o PSB). Quando os mesmos testes tomam como variável dependente a proporção de

Tabela 2 - Modelo explicativo para o peso da face pública (ocupantes de cargos eletivos e de confiança)

\begin{tabular}{|c|c|c|c|c|c|}
\hline \multicolumn{6}{|l|}{ Resumo do modelo } \\
\hline Modelo & $\mathbf{R}$ & R quadrado & \multicolumn{3}{|l|}{ Erro padrão da estimativa } \\
\hline 1 & $0,823^{\mathrm{a}}$ & 0,678 & 14,37 & & \\
\hline 2 & $0,856^{\mathrm{b}}$ & 0,732 & 13,18 & & \\
\hline 3 & $0,865^{\mathrm{c}}$ & 0,748 & 12,86 & & \\
\hline \multicolumn{6}{|l|}{ Coeficientes } \\
\hline \multirow[t]{2}{*}{ Modelo } & \multicolumn{2}{|c|}{ Coeficientes não padronizados } & Coeficientes padronizados & $\mathbf{t}$ & Significância \\
\hline & B & Modelo padrão & Beta & & \\
\hline 1 (Constante) & 43,039 & 2,362 & & 18,220 & 0,000 \\
\hline origem/campo & 41,987 & 3,066 & $\mathbf{0 , 8 2 3}$ & 13,692 & $0,000 *$ \\
\hline 2 (Constante) & 27,139 & 4,347 & & 6,242 & 0,000 \\
\hline origem/campo & 39,211 & 2,889 & 0,769 & 13,575 & $0,000 *$ \\
\hline gov x oposição & 12,006 & 2,846 & 0,239 & 4,218 & $0,000 *$ \\
\hline 3 (Constante) & 29,083 & 4,324 & & 6,726 & 0,000 \\
\hline origem/campo & 41,902 & 3,047 & 0,822 & 13,753 & $0,000 *$ \\
\hline gov x oposição & 10,538 & 2,848 & 0,210 & 3,700 & $0,000 *$ \\
\hline dummy PSDB & $-9,769$ & 4,198 & $-0,136$ & $-2,327$ & $0,022 *$ \\
\hline
\end{tabular}

Notas: Considerou-se cada formação de executiva como uma observação ( $\mathrm{N}=91)$, sendo utilizado um teste de regressão linear múltipla com método stepwise. Variável dependente: face pública. a. Preditores: (Constante), origem/campo. b. Preditores: (Constante), origem/campo, oposição x governo. c. Preditores: (Constante), origem/campo, oposição x governo, dummy PSDB. * Coeficientes são significativos.

Fonte: Elaboração própria 
dirigentes sem histórico de cargos, os resultados recolocam o PT como distinto: a variável dummy PT passa a ser a segunda mais relevante em termos de poder explicativo, atrás apenas da origem/campo. Além da origem e do fator PSDB, a variável governo x oposição também possui alguma capacidade explicativa (acrescentando mais ao modelo do que a variável PSDB).

\section{Por trás dos números}

Os padrões gerais apontados nos parágrafos anteriores escondem algumas nuances relevantes, que dizem respeito ao controle efetivo da máquina partidária. Principalmente a partir dos anos 1990, verifica-se em vários partidos um processo de especialização funcional nas executivas nacionais, com a indicação de dirigentes devotados exclusivamente à máquina ou mandatários de menor destaque nacional para a ocupação dos cargos considerados chave - em geral, aqueles mais diretamente envolvidos no controle das zonas de incerteza do partido (Panebianco 1995). Delega-se, assim, ao secretário-geral, secretário de organização ou ao tesoureiro a responsabilidade pela gestão cotidiana do partido; em regra, tais dirigentes permanecem no cargo por vários mandatos.

O deputado federal Saulo Queiroz (Mato Grosso do Sul) ocupou a secretaria geral do PFL/DEM por duas gestões, e foi tesoureiro nacional do partido três vezes (de um total de 12 gestões, excluída a Comissão Nacional Provisória), enquanto o deputado maranhense César Bandeira esteve à frente da tesouraria por três gestões seguidas, entre 1996 e 2003. Na liderança do processo de fundação do PPB em 1995, Esperidião Amin colocou como homem forte da máquina partidária o deputado Benedito Domingos (vice-governador de Joaquim Roriz no Distrito Federal), que ocuparia o cargo de secretário-geral do partido por ao menos seis gestões (considerando que há lacunas nos dados), além de chefiar a tesouraria entre 2003 e 2005. Após Domingos, o deputado federal catarinense Leodegar Tiscoski esteve à frente do caixa do partido por quase dez anos, metade deles em parceria com José Janene, deputado implicado no escândalo do mensalão. Já no PSDB um núcleo decisório mais estável só se conformaria após a derrota eleitoral de 2002. Nesse núcleo, figuram de modo recorrente nos cargos chave da máquina o ex-ministro do governo FHC Eduardo Jorge Pereira (no cargo de vice-presidente executivo), os deputados federais Rodrigo de Castro (ligado a Aécio Neves) e Márcio Fortes, além de Sérgio Moreira da Silva, secretário executivo sem histórico de cargos externos.

Atuando como representante oficial do partido nas questões cotidianas, e com um perfil mais burocrático (sem histórico de cargos eletivos), Carlos Siqueira de Barros ocupou o posto de primeiro secretário nacional do PSB de 1995 a 2014, completando oito gestões seguidas e sobrevivendo à transição geracional entre Miguel Arraes e Eduardo Campos. Com a morte do ex-governador de Pernambuco em 2014, ele foi eleito presidente nacional da sigla. Apenas Roberto Amaral - presidente por alguns dias em 2014, e afastado da cúpula por discordar da aproximação do partido em relação ao PSDB - era mais longevo na executiva nacional: estava presente de modo ininterrupto desde a comissão provisória formada em 1985, ocupando diversos cargos e passando a ser o primeiro vice-presidente da sigla a partir de 2003. Nas finanças, o deputado federal Alexandre Cardoso foi o homem forte entre 1999 e 2005, quando passou o comando para o deputado paulista Márcio França, ainda no posto em 2014 (três mandatos para cada). Também integra o núcleo decisório atual da sigla o deputado, senador e governador Renato Casagrande, secretário-geral do PSB desde 2001.

Já o PDT foi administrado durante duas décadas por um petit comité intimamente ligado a Leonel Brizola, formado principalmente por dirigentes sem trajetória de cargos eletivos, como Hésio Cordeiro, Carlos Roberto Si- 
18 A executiva nacional eleita em 2001 apontou o deputado federal João Henrique, do Piauí, para o cargo de secretário-geral. queira Castro e Manoel Dias. Ocupando posições de destaque nesse núcleo decisório durante várias gestões - principalmente a secretaria de finanças - o ex-deputado federal Carlos Lupi assumiria a presidência pedetista após a morte de Brizola em 2004, mantendo Manoel Dias como homem forte da máquina na condição de secretário-geral (cargo que ocupa desde 2001). Já na estrutura federalizada do PMDB, com a divisão de espaços da executiva nacional entre as seções estaduais (cf. Ferreira 2002), acordo tácito coloca, desde 1986, a secretaria geral sob controle do diretório de Minas Gerais. Com apenas uma exceção, as 11 gestões formadas desde então indicaram para o cargo apenas deputados federais mineiros: Milton Reis, Tarcísio Delgado, Mello Reis, Joaquim de Melo Freire, Marcos Lima, Saraiva Felipe (antes de se tornar destaque como ministro da Saúde) e Mauro Lopes ${ }^{18}$.

No PT, as secretarias geral, de organização e de finanças sempre foram os cargos mais cobiçados na máquina (depois da presidência), constituindo-se nos principais espólios e recursos a serem negociados e disputados entre as correntes, após cada processo de renovação diretiva. Nos anos oitenta essa disputa ficava restrita ao interior da Articulação, já que a formação da executiva nacional seguia uma lógica majoritária. Assim, na primeira década do PT revezavam-se nos cargos chave da máquina alguns dos líderes mais relevantes da tendência, centrais na fundação do partido, como Lula, Jacó Bittar, Francisco Weffort, Clóvis Ilgenfritz, e os deputados Olívio Dutra, Luiz Dulci e Freitas Diniz. A partir do $7^{\circ}$ Encontro Nacional (1990), com a adoção da proporcionalidade na formação da executiva, as oscilações no controle desses postos passaram a refletir a correlação de forças no interior do partido. Esse período de transição no interior do PT (marcado pelo expurgo de algumas facções mais radicais) foi liderado por José Dirceu, na condição de secretário-geral do partido entre 1988 e 1993, e acumulando o cargo com a secretaria de organização no último ano (além de ser deputado estadual até 1990, quando se elege deputado federal). Após o hiato de dois anos em que as tendências de esquerda controlaram o partido, a formação de uma nova coalizão dominante no $10^{\circ}$ Encontro Nacional, em 1995 (o Campo Majoritário), colocou Dirceu na presidência do PT, dando início a um processo de estabilização no controle dos cargos chave da máquina. Se nas primeiras gestões as maiores tendências da esquerda (Articulação de Esquerda e Democracia Socialista) ainda conseguiram acesso a esses cargos (secretarias geral e de organização), a partir de 1999 se estabelece uma mini-oligarquia de contornos burocráticos na executiva, estreitamente vinculada a Dirceu. Delubio Soares à frente das finanças (antes ele ocupara a secretaria sindical), Ozéas Duarte como secretário de comunicação, e Silvio Pereira nas secretarias geral e de organização foram os membros mais destacados desse grupo (Ribeiro 2010).

\section{Conclusões}

$\mathrm{O}$ artigo consistiu em um primeiro esforço no sentido de traçar um perfil das elites dos partidos políticos brasileiros. Em primeiro lugar, os resultados contestam uma das suposições mais arraigadas na literatura: a de que as instâncias centrais dos partidos brasileiros seriam monoliticamente controladas por deputados federais e senadores. Essa suposição, nunca verificada empiricamente, sustenta-se apenas para PMDB, PP e PFL/DEM. Para os partidos de esquerda e, ainda que em menor escala, também para o PSDB, alguns tons de cinza são necessários para matizar a discussão. Os dirigentes sem qualquer histórico de cargos são bastante raros nas legendas de centro e direita, e mais frequentes no PT do que no PSB e no PDT. A origem do partido aparece como variável explicativa principal para o maior ou menor grau de domínio da face pública sobre as executivas. Entre os partidos analisados, o mais jovem possui 26 anos (PSDB). Mesmo após décadas, todos ainda reverberam os padrões, as opções 
dos atores hegemônicos e os conflitos que marcaram seus processos fundacionais, o que reforça a importância de se atentar para o modelo originário de cada partido (Panebianco 1995). Indissociáveis do fator origem, os padrões de recrutamento e as estruturas de oportunidades consolidados ao longo dos anos se expressam nas distintas fisionomias das elites partidárias - com a horizontalidade sendo contestável nos partidos de esquerda. Em perspectiva comparada, o impacto da origem do partido, das estruturas de oportunidades e da participação no governo aproxima o caso brasileiro de outros contextos nacionais. $\mathrm{O}$ momento de fundação do sistema partidário não parece ser uma variável explicativa relevante na comparação entre países, na medida em que a hegemonia da face pública mostra-se um fenômeno generalizado, que afeta tanto as democracias mais tradicionais quanto os sistemas redemocratizados a partir dos anos setenta, como Portugal, Espanha e os países pós-comunistas (Van Biezen 2000; Detterbeck 2005; Katz \& Mair 2009).

Quais as implicações mais profundas desses resultados? Na linha do que coloca Eldersveld (1964), os dados sugerem que é mais apropriado falar em elites partidárias do que em uma elite unida, composta por líderes de fisionomia similar e que compartilham interesses. O caráter multifacetado das cúpulas, na medida em que pode comprometer a coesão nessas instâncias, é um fator que joga contra a hipótese de oligarquização (idem, pp. 160-168; Panebianco 1995). No entanto, o fechamento do foco nos núcleos decisórios das siglas aponta para a possibilidade de que essa instância informal, composta pelos cargos nevrálgicos da máquina, ostente uma fisionomia um pouco distinta em relação às executivas como um todo, no sentido de menor parlamentarização e uma grande estabilidade dos dirigentes em seus cargos. Nesse sentido, cabe explorar mais a fundo as variações entre executiva e seu núcleo, que podem apontar para combinações diferentes entre estabilidade, mobilidade e aspirações dos dirigentes (algo que será feito em trabalhos futuros).

Ainda que não monolítica, a hegemonia da face pública nas direções transforma em letra morta as regras, presentes nos estatutos de todas as legendas brasileiras, que preveem a disciplina das bancadas perante a executiva nacional. Com recursos institucionais de sobra para controlar a convenção nacional, o diretório e, consequentemente, a executiva, não há nem mesmo a necessidade de se rever tais dispositivos. No PT, que possui esse histórico de tensões, os encontros representativos da base e, a partir de 2001, as eleições diretas, sempre conformaram outra dinâmica interna, permitindo maior espaço para os não eleitos nas executivas. No entanto, os parlamentares petistas também controlam os mesmos recursos que são vitais a todas as siglas, e desfrutam de papel central nas tendências, dispondo de recursos decisivos para os militantes e para a disputa interna - cargos, recursos financeiros etc. Além disso, as eleições diretas hoje incentivam a presença dos políticos de grande capital eleitoral à frente das chapas para os diretórios, de modo a maximizar a votação interna na tendência. Com essa soma de fatores, mesmo as executivas petistas se mostram, hoje, pouco capazes de refrear o poder da face pública (Ribeiro 2014).

A manutenção de dispositivos que poderiam colocar em risco a autonomia das bancadas não é sinônimo de inércia: os dirigentes dos partidos brasileiros têm promovido reformas internas com alguma frequência, quase sempre com o vetor de centralização do poder nas instâncias menores, em detrimento de convenções, congressos e diretórios. A implantação de mecanismos de representação ex officio surge como estratégia apenas no PSDB e no DEM, no bojo de reformas mais amplas que visavam garantir o controle do partido por elites mais restritas. É nesse sentido que se insere o fortalecimento dos Conselhos Nacionais, a transferência de competências dos diretórios para as executivas, e a concessão de poderes monocráticos aos presidentes. Especificamente em relação ao PSDB, os conflitos regionais explicam grande parte das reformas 
${ }^{19}$ Estatuto do PSDB (2013).

recentes. O fortalecimento do Conselho Político Nacional a partir de 1999, e a limitação progressiva de seu número de membros até se transformar em um petit comité de apenas seis integrantes reforçaram o domínio paulista na sigla, garantindo a presença de ao menos três caciques do estado - FHC, José Serra e Geraldo Alckmin - responsáveis por indicar (ao lado do presidente nacional) outros dois dos membros da instância. Ao assumir a presidência da legenda em 2013, Aécio Neves tratou de desidratar essa instância "paulista", tendo no horizonte a disputa presidencial de 2014. Ele reforçou as prerrogativas da executiva nacional e de seu presidente, que passou a contar com poderes monocráticos de decisão, inclusive para intervir liminarmente sobre quaisquer órgãos partidários; criou o cargo de diretor de gestão corporativa para administrar o dia a dia do partido, a ser preenchido por indicação do presidente e podendo desempenhar todas as competências por ele delegadas (o diretor é remunerado, não pode exercer mandato eletivo, e não necessariamente é membro da executiva) e instituiu um núcleo duro decisório na executiva, o Comitê de Governança Estratégica, formado pelo presidente e pelos seis vice-presidentes, e coordenado por um destes, indicado pelo presidente ${ }^{19}$.

Em outros sistemas partidários, a direção acumula certos recursos institucionais que contrabalançam o poder dos parlamentares, como a centralização e distribuição dos recursos públicos destinados ao financiamento das campanhas, e o controle do processo de seleção de candidatos, em sistemas proporcionais de lista fechada. Nesses países, talvez nem mesmo a sobreposição entre dirigentes e parlamentares implique no fim das tensões entre direção e bancada - algo carente de comprovação, no entanto (Van Biezen 2000). No Brasil, em lugar da direção partidária, o vínculo de disciplina do parlamentar se volta em geral ao líder de bancada, intermediador decisivo para acesso a cargos no governo, à liberação de emendas, e aos postos nas mesas diretoras e comissões do Congresso. Os políticos possuem um controle muito maior sobre suas estratégias e fontes de financiamento eleitoral, e a preocupação com a lista se traduziria na presença nas instâncias estaduais - convenções e diretórios - e não nas nacionais. Por que os políticos eleitos se fazem presentes, então, nas executivas nacionais?

Como especulado por V.O. Key (1962) em seu trabalho clássico, a chave da resposta pode repousar na busca de coesão e articulação entre distintos elementos do corpo partidário - mais premente ainda em estados federativos, sistemas presidencialistas e (acrescentamos nós) em cenários multipartidários que implicam em governos de coalizão. A constante presença dos parlamentares federais pode estar vinculada à busca de coesão entre direção e bancada, minimizando tensões e dissensões, promovendo a disciplina e a fidelidade ao partido etc. Quando o partido comanda ou integra o governo, a executiva nacional passa a ser um elemento coesivo ainda mais importante. Nesses momentos, os ocupantes de cargos não eletivos no governo podem ser impelidos - como tributo por sua indicação - a atuar como porta-vozes da Presidência da República ou de outros setores da administração junto às executivas nacionais, ajudando a amortecer e acomodar eventuais atritos e divergências. A participação de comissionados no governo federal em quase todas as executivas "de governo" reforça essa ideia.

No entanto, o papel coesivo das executivas pode ir além dessa integração horizontal. Os dados desagregados indicam que a maioria dos political appointees que participam das executivas (57 casos contra 41) ocupava cargos de confiança em administrações estaduais e locais integradas ou comandadas pelo partido. A indicação de um apadrinhado local/regional para compor a executiva nacional pode ser uma estratégia de líderes regionais (parlamentares, governadores, prefeitos de capitais etc.) para contar com uma "base avançada" de influência nas decisões centrais do partido. Na medida em que quase todos os 
políticos têm suas trajetórias atreladas à dinâmica estadual, a presença (pessoal ou através de aliados) na instância nacional minimiza as chances de que seus interesses regionais sejam contrariados. As instâncias nacionais podem constituir, principalmente para os partidos mais descentralizados - como o PMDB o único espaço de acomodação e negociação dos interesses e estratégias muitas vezes conflitantes das elites regionais. A influência direta ou indireta sobre a executiva pode assegurar, em última instância, o veto contra coligações indesejadas, a costura de alianças nacionais que reforcem as regionais etc. Para as legendas que buscam construir projetos eleitorais nacionalmente unificados como PT e PSDB - a demanda por coesão é ainda maior. Como fica claro no caso do PSDB sob o comando de Aécio Neves, o controle da executiva nacional é vital para gerar a coesão entre partido e projeto presidencial. Coligações nacionais e estaduais, negociações sobre palanques regionais, captação centralizada de doações de grandes empresas: tudo isso passa pela articulação com a executiva nacional. Como aponta Key (idem, pp. 499-500), a presença pessoal de líderes regionais ou a indicação de correligionários podem constituir, portanto, também um recurso de integração vertical, especialmente importante em contextos federativos e em partidos altamente descentralizados (como é a regra nos EUA e em muitos partidos brasileiros).

A distinção analítica entre face pública e direção partidária perde grande parte de seu significado e, consequentemente, de sua utilidade para analisar partidos fortemente parlamentarizados como PMDB, DEM e PP. Nesses casos, não é exagero tomar a executiva nacional como prolongamento das bancadas no Congresso, com o caso extremo da "executiva-bancada" do PP, partido que parece ajustar o tamanho de sua instância principal à representação na Câmara: todos os deputados federais eleitos pela sigla em 2002 (49) e 2006 (41) foram incluídos nas executivas formadas em 2005, 2007 e 2009, com os eleitos em 2010 (44) ingressando posteriormente. Se face pública e direção podem se tornar indistinguíveis, a entrada de membros do governo federal nas executivas levanta a pertinência de se separar as bancadas dos membros no governo, como advoga Key (idem, p. 260). De qualquer maneira, com duas, três ou quatro faces, essa estratégia de desagregação precisa ser encarada como mera ferramenta analítica, simplificadora da complexa realidade interna do partido, e útil apenas em alguns tipos de análise.

Por fim, os critérios de formação e o perfil das executivas nacionais, bem como seu maior ativismo intervencionista nos últimos anos, convergem para uma possível transformação organizacional dos principais partidos brasileiros. De modelos federalizados, talvez suas estruturas estejam se convertendo em estratarquias: menos centralizadas do que as hierarquias tradicionais, mas sem a representação interna regionalizada (como se dá no modelo federalizado), e com um equilíbrio tênue entre a autonomia regional e a centralização de decisões importantes nas cúpulas nacionais ${ }^{20}$. A análise dessa possível transformação se coloca como um interessante desafio de pesquisa para os próximos anos.

foi desenvolvido por

Eldersveld (1964), e retomado Mair (1995), Carty (2004) e

Bolleyer (2012).
Esses primeiros resultados agregados precisam ser complementados por investigações que se aprofundem sobre o perfil das elites partidárias, sobretudo em termos de sua trajetória prévia à entrada na executiva. Qual é o peso das migrações de parlamentares para a formação das instâncias? Os partidos de esquerda são realmente mais fechados a um padrão horizontal de recrutamento, no sentido de vetar a entrada de recém-filiados nas instâncias principais? Esses dirigentes nacionais passaram anteriormente por instâncias locais e estaduais? Qual é a rotatividade dos dirigentes desses órgãos? Existem oligarquias dirigentes nos partidos? Essas são algumas das questões a serem respondidas acerca de um tema pouquíssimo explorado pela literatura da área. 
Pedro Floriano Ribeiro (pfribeiro@ufscar.br) é Doutor em Ciência Política pela Universidade Federal de São Carlos (UFSCar) e Professor do Programa de Pós-Graduação em Ciência Política da mesma universidade.

\section{Referências}

Bolleyer, N.; Gauja, A. 2013. Parliamentary Salaries as a Party Resource: Party organizational power in Westminster democracies. Party Politics, 19(5), pp. 778-797.

Bolleyer, N. 2012. New Party Organization in Western Europe: Of party hierarchies, stratarchies and federations. Party Politics, 18(3), pp. 315-336.

Carty, K. 2004. Parties as Franchise Systems: The stratarchical organizational imperative. Party Politics, 10(1), pp. 5-24.

Detterbeck, K. 2005. Cartel Parties in Western Europe? Party Politics, 11(2), pp. 173-191.

Duverger, M. 1987. Os partidos políticos. Rio de Janeiro: Guanabara.

Eldersveld, S. 1964. Political Parties: A behavioral analysis. Chicago: Rand McNally.

Ferreira, P.D. 2002. PFL x PMDB: Marchas e Contramarchas (1982-2000). Goiânia: Editora Alternativa.

Figueiredo, A.; Limongi, F. 2007. Instituições políticas e governabilidade: desempenho do governo e apoio legislativo na democracia brasileira. In C.R. Melo; M. Alcántara, eds. A democracia brasileira: balanço e perspectivas para o século 21. Belo Horizonte: UFMG.

Katz, R. 2014. No Man Can Serve Two Masters: Party politicians, party members, citizens and principal-agent models of democracy. Party Politics, 20(2), pp. 183-193.

Katz, R.; Mair, P. 1995. Changing Models of Party Organization and Party Democracy: The Emergence of the Cartel Party. Party Politics, 1(1), pp. 5-28. 2009. The Cartel Party Thesis: A Restatement. Perspectives on Politics, 7(4), pp. 753-766.

Key, V.O. 1962. Política, Partidos y Grupos de Presión. Madrid: Instituto de Estudios Políticos.

Lawson, K. 1976. The Comparative Study of Political Parties. New York: St. Martin's Press.

Mair, P. 2005. Democracy Beyond Parties. Working Paper 05/06. Center for the Study of Democracy, University of California. . 2009. Representative vs. Responsible Government. Working Paper 09/8. Max Planck Institute for the Study of Societies.

Marenco, A.; Serna, M. 2007. Por que carreiras políticas na esquerda e na direita não são iguais? Recrutamento legislativo em Brasil, Chile e Uruguai. Revista Brasileira de Ciências Sociais, 22(64), pp. 93-113.

Margetts, H. 2006. Cyber Parties. In R. Katz; W. Crotty, eds. Handbook of Party Politics. London: Sage.

Meneguello, R. 1998. Partidos e governos no Brasil contemporâneo (1985-1997). São Paulo: Paz e Terra.

Michels, R. 2001. Para uma sociologia dos partidos políticos na democracia moderna. Lisboa: Antígona.

Panebianco, A. 1995. Modelos de partido: organización y poder en los partidos políticos. Madrid: Alianza Editorial.

Power, T.; Zucco, C. 2011. O Congresso por ele mesmo: autopercepções da classe política brasileira. Belo Horizonte: UFMG.

Praça, S.; Freitas, A.; Hoepers, B. 2012. A rotatividade dos servidores de confiança no governo federal brasileiro, $2010-2011$. Novos Estudos, 94, pp. 91-107

Ribeiro, P.F. 2010. Dos sindicatos ao governo: a organização nacional do PT de 1980 a 2005. São Carlos/São Paulo: EdUFSCar/Fapesp.

. 2013a. Organização e poder nos partidos brasileiros: uma análise dos estatutos. Revista Brasileira de Ciência Política, 10 , pp. 225-265.

2013b. El modelo de partido cartel y el sistema de partidos de Brasil. Revista de Ciencia Política, 33(3), pp. 607-629.

. 2014. An Amphibian Party? Organisational Change and Adaptation in the Brazilian Workers' Party (1980-2012). Journal of Latin American Studies, 46(1), pp. 87-119.

Sartori, G. 1981. A Política: lógica e método nas ciências sociais. Brasília: UnB.

Souza, M.C.C. 1983. Estado e partidos políticos no Brasil (1930 a 1964). São Paulo: Alfa-Ômega.

Tarouco, G.; Madeira, R.M. 2013. Esquerda e direita no sistema partidário brasileiro: análise de conteúdo de documentos programáticos. Revista Debates, 7(2), pp. 93-114.

Van Biezen, I. 2000. On the Internal Balance of Party Power: Party Organizations in New Democracies. Party Politics, 6(4), pp. 395-417.

Zucco, C. 2011. Esquerda, Direita e Governo: a ideologia dos partidos políticos brasileiros. In T. Power \& C. Zucco, eds. $O$ Congresso por ele mesmo: autopercepções da classe política brasileira. Belo Horizonte: UFMG.

\section{Outras fontes}

Código de Ética e Disciplina do PT. 2009. Aprovado pelo diretório nacional em junho de 2009.

Estatuto do PT. 2001. Aprovado pelo diretório nacional em março de 2001.

Estatuto do PT. 2012. Aprovado pelo diretório nacional em fevereiro de 2012, incorporando alterações aprovadas no $4^{\circ}$ Congresso Nacional Extraordinário (setembro de 2011).

Estatuto do PSB. 2005. Aprovado pelo X Congresso Nacional, em agosto de 2005.

Estatuto do PDT. 1996. Aprovado pela Convenção Nacional de fevereiro de 1996.

Estatuto do PDT. 1999. Aprovado pela Convenção Nacional de agosto de 1999.

Estatuto do PMDB. 1996. Aprovado pela Convenção Nacional Extraordinária de março de 1996. 
Estatuto do PMDB. 2007. Aprovado pela Convenção Nacional de março de 2007.

Estatuto do PMDB. 2013. Aprovado pela Convenção Nacional de março de 2013.

Estatuto do PSDB. 1999. Aprovado pela Convenção Nacional Extraordinária de maio de 1999.

Estatuto do PSDB. 2003. Aprovado pela VII Convenção Nacional, em novembro de 2003.

Estatuto do PSDB. 2013. Aprovado pela XI Convenção Nacional, em maio de 2013.

Estatuto do PFL. 2003. Aprovado pela Convenção Nacional de maio de 2003.

Estatuto do DEM. 2007. Aprovado pela Convenção Nacional de dezembro de 2007.

Estatuto do PPB. 1996. Aprovado pela Convenção Nacional Extraordinária de março de 1996.

Estatuto do PP. 2011. Aprovado pela Convenção Nacional de abril de 2011.

\section{ABSTRACT}

We know almost nothing about the national leaderships of the Brazilian political parties, spaces for disputes and deliberations on relevant aspects of national political life. The aim here is to begin to open the black box of these spaces, outlining a profile of the Brazilian party elites. Unpublished data on the national executive committees formed between 1980 and 2013 are used, of the seven major parties: PT, PSB, PDT, PMDB, PSDB, DEM and PP. The data on executive committees were obtained from the TSE, DHBB (FGV) and the parties themselves. Besides pointing out the differences between the parties with respect to the weight of the 'party in public office' in the committees (elected representatives and political appointees), we assessed the statistical explanatory power of some variables to understanding the patterns and differences observed: ideology and party origin, its electoral strength, and participation in the federal government. Going beyond the numbers, are presented some names of leaders who stand out in party committees, stressing that the decision-making core of the machines (general secretary, finance etc.) may have a slightly different face compared to the committees as a whole. An integrated explanatory model was able to explain most of the observed variability, suggesting the party origin (internal or not to the parliament) as the main predictor. Parties with internal origin (which are the center and right-wing parties) tend to have more parliamentarized committees, while those with no internal origin (the left-wing parties) have fewer MPs; the PT national committees have more leaders with no records of public office. The results reinforce the relevance of the party genetic model, and contest one of the most entrenched assumptions in the literature: that central bodies of Brazilian parties are monolithically controlled by federal deputies and senators. It is more appropriate to talk in party elites than in one united elite. Behind the constant presence of representatives and political appointees in the national committees is the pursuit of cohesion and coordination between different elements of the party organism, both horizontally (national leadership, federal representatives and federal government) as in the vertical-federal vector (national leadership and subnational governments, representatives and party branches).

KEYWORDS: political parties; political elites; party genetic model; national executive committees; ideology. 


\section{Apêndice 1. Estatísticas}

Tabela 1A - Comparação de médias: executivas formadas no governo x executivas formadas na oposição Tabela 2A - Teste T: perfil da executiva e variável governo x oposição

Tabela 3A - Estatísticas descritivas: face pública total por campo ideológico

Tabela 4A - ANOVA: comparação entre médias da face pública total por campo ideológico

Tabela 5A - Testes de robustez da igualdade de médias: médias da face pública total por campo ideológico

Tabela 6A - Testes Post hoc de comparações múltiplas: médias da face pública total por campo ideológico

Tabela 7A - Subconjuntos homogêneos: médias da face pública total por campo ideológico

Tabela 8A - Estatísticas descritivas: face pública total por origem do partido

Tabela 9A - ANOVA: comparação entre médias da face pública total por origem do partido

Tabela 10A - Testes de robustez da igualdade de médias: médias da face pública total por origem do partido

Tabela 11A - Testes Post hoc de comparações múltiplas: médias da face pública total por origem do partido

Tabela 12A - Subconjuntos homogêneos: médias da face pública total por origem do partido

Gráfico 1A - Dirigentes com cargos eletivos ou de confiança (\%) nas executivas formadas no governo e nas executivas formadas na oposição (médias)

Gráfico 2A - Dirigentes sem histórico de cargos (\%) nas executivas formadas no governo e nas executivas formadas na oposição (médias) 
Tabela 1A - Comparação de médias: executivas formadas no governo x executivas formadas na oposição

\begin{tabular}{|c|c|c|c|c|c|}
\hline & Gov. x oposição & $\mathbf{N}$ & Média & Desvio padrão & Erro padrão da média \\
\hline \multirow[t]{2}{*}{ Mandatários eleitos } & oposição & 49 & 55,44 & 26,25 & 3,75 \\
\hline & governo & 42 & 72,54 & 23,21 & 3,58 \\
\hline \multirow[t]{2}{*}{ Ocupantes cargos conf. total } & oposição & 49 & 2,91 & 4,04 & 0,58 \\
\hline & governo & 42 & 6,62 & 7,40 & 1,14 \\
\hline \multirow[t]{2}{*}{ Ocupantes cargos conf. gov. fed. } & oposição & 49 & 0,32 & 1,83 & 0,26 \\
\hline & governo & 42 & 3,95 & 6,15 & 0,95 \\
\hline \multirow[t]{2}{*}{ Face pública total } & oposição & 49 & 58,35 & 25,36 & 3,62 \\
\hline & governo & 42 & 79,16 & 20,00 & 3,09 \\
\hline \multirow[t]{2}{*}{ Sem histórico de cargos } & oposição & 49 & 19,11 & 23,21 & 3,32 \\
\hline & governo & 42 & 7,87 & 12,37 & 1,91 \\
\hline
\end{tabular}

Fonte: Elaboração própria, tomando cada formação de executiva como um caso $(\mathrm{N}$ total = 91). 


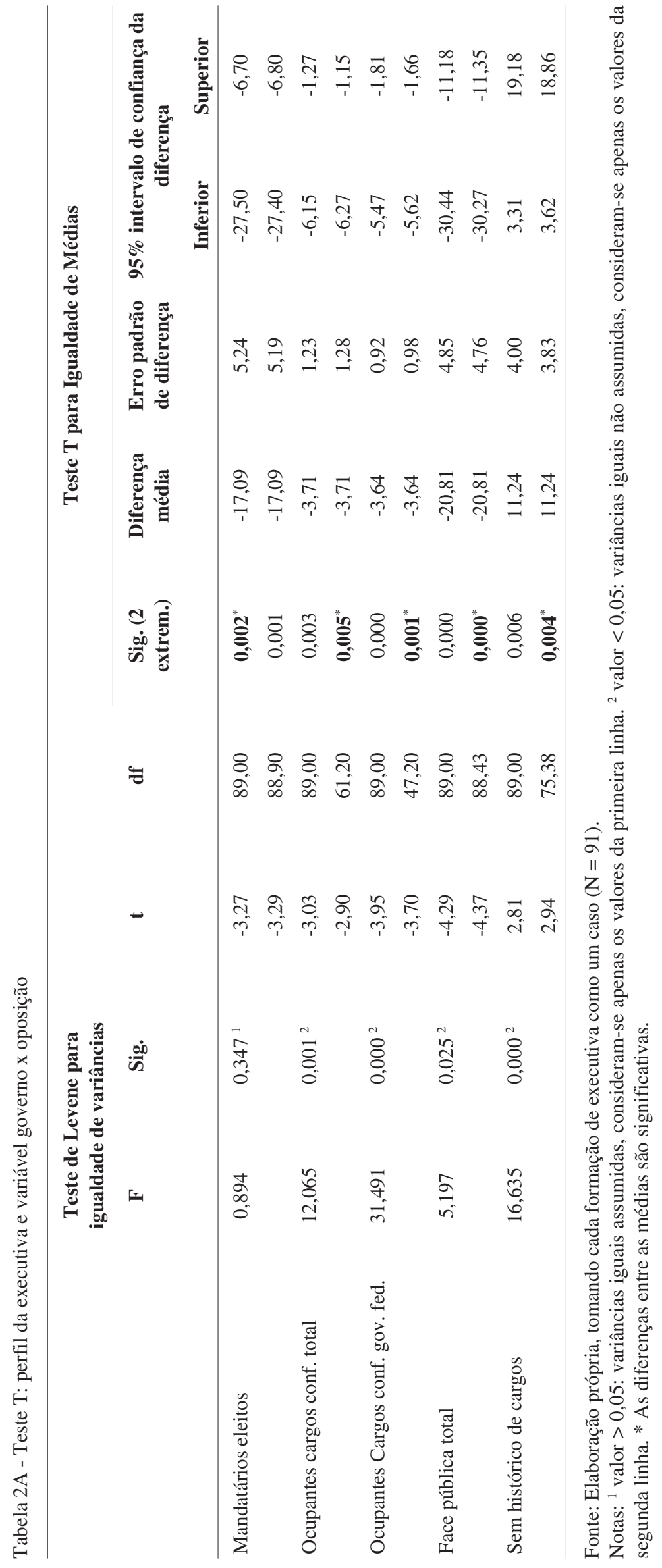


Tabela 3A - Estatísticas descritivas: face pública total por campo ideológico

\begin{tabular}{|c|c|c|c|c|c|c|c|c|}
\hline & \multirow[t]{2}{*}{$\mathbf{N}$} & \multirow[t]{2}{*}{ Média } & \multirow{2}{*}{$\begin{array}{l}\text { Desvio } \\
\text { padrão }\end{array}$} & \multirow{2}{*}{$\begin{array}{l}\text { Modelo } \\
\text { padrão }\end{array}$} & \multicolumn{2}{|c|}{ Intervalo de confiança de $95 \%$ para média } & \multirow[t]{2}{*}{ Mínimo } & \multirow[t]{2}{*}{ Máximo } \\
\hline & & & & & Limite inferior & Limite superior & & \\
\hline Esquerda & 37 & 43,04 & 16,33 & 2,68 & 37,59 & 48,48 & 12,50 & 69,57 \\
\hline Centro & 29 & 83,02 & 15,47 & 2,87 & 77,13 & 88,90 & 40,00 & 100,00 \\
\hline Direita & 25 & 87,35 & 8,70 & 1,74 & 83,76 & 90,95 & 66,67 & 100,00 \\
\hline Total & 91 & 67,96 & 25,18 & 2,64 & 62,71 & 73,20 & 12,50 & 100,00 \\
\hline
\end{tabular}

Fonte: Elaboração própria

Nota: Face pública total: mandatários eleitos e ocupantes de cargos de confiança. Esquerda: PT, PSB, PDT. Centro: PSDB e PMDB. Direita: PFL/DEM e PP.

Tabela 4A - ANOVA: comparação entre médias da face pública total por campo ideológico

\begin{tabular}{lccccc}
\hline & Soma dos quadrados & df & Quadrado Médio & F & Sig. \\
\hline Entre Grupos & 38958,50 & 2 & 19479,25 & 94,59 & $\mathbf{0 , 0 0 0}^{*}$ \\
Nos grupos & 18121,86 & 88 & 205,93 & & \\
Total & 57080,36 & 90 & & & \\
\hline
\end{tabular}

Fonte: Elaboração própria.

Nota: * As diferenças entre as médias são significativas.

Tabela 5A - Testes de robustez da igualdade de médias: médias da face pública total por campo ideológico

\begin{tabular}{lcccc}
\hline & Estatística & df1 & df2 & Sig. \\
\hline Welch & 98,49 & 2 & 56,87 & $0,000^{*}$ \\
Brown-Forsythe & 103,53 & 2 & 79,91 & $0,000^{*}$ \\
\hline
\end{tabular}

Fonte: Elaboração própria

Nota: * As diferenças entre as médias são significativas. 
Tabela 6A - Testes Post hoc de comparações múltiplas: médias da face pública total por campo ideológico

\begin{tabular}{|c|c|c|c|c|c|c|c|}
\hline & \multirow{2}{*}{$\begin{array}{l}\text { (I) campos } \\
\text { ideológicos }\end{array}$} & \multirow{2}{*}{$\begin{array}{l}\text { (J) campos } \\
\text { ideológicos }\end{array}$} & \multirow{2}{*}{$\begin{array}{c}\text { Diferença } \\
\text { média (I-J) }\end{array}$} & \multirow{2}{*}{$\begin{array}{l}\text { Modelo } \\
\text { padrão }\end{array}$} & \multirow[t]{2}{*}{ Sig. } & \multicolumn{2}{|c|}{ Intervalo de confiança $95 \%$} \\
\hline & & & & & & Limite inferior & Limite superior \\
\hline \multirow[t]{6}{*}{ Scheffe } & \multirow[t]{2}{*}{ Esquerda } & Centro & $-39,98^{*}$ & 3,56 & $0,000^{*}$ & $-48,84^{*}$ & $-31,12$ \\
\hline & & Direita & $-44,32^{*}$ & 3,72 & $0,000^{*}$ & $-53,57^{*}$ & $-35,07$ \\
\hline & \multirow[t]{2}{*}{ Centro } & Esquerda & $39,98^{*}$ & 3,56 & $0,000^{*}$ & $31,12^{*}$ & 48,84 \\
\hline & & Direita & $-4,34$ & 3,92 & 0,544 & $-14,09$ & 5,41 \\
\hline & \multirow[t]{2}{*}{ Direita } & Esquerda & $44,32^{*}$ & 3,72 & $0,000^{*}$ & $35,07^{*}$ & 53,57 \\
\hline & & Centro & 4,34 & 3,92 & 0,544 & $-5,41$ & 14,09 \\
\hline \multirow[t]{6}{*}{ LSD } & \multirow[t]{2}{*}{ Esquerda } & Centro & $-39,98^{*}$ & 3,56 & $0,000^{*}$ & $-47,05^{*}$ & $-32,91$ \\
\hline & & Direita & $-44,32^{*}$ & 3,72 & $0,000^{*}$ & $-51,70^{*}$ & $-36,93$ \\
\hline & \multirow[t]{2}{*}{ Centro } & Esquerda & $39,98^{*}$ & 3,56 & $0,000^{*}$ & $32,91^{*}$ & 47,05 \\
\hline & & Direita & $-4,34$ & 3,92 & 0,271 & $-12,12$ & 3,45 \\
\hline & \multirow[t]{2}{*}{ Direita } & Esquerda & $44,32^{*}$ & 3,72 & $0,000^{*}$ & $36,93^{*}$ & 51,70 \\
\hline & & Centro & 4,34 & 3,92 & 0,271 & $-3,45$ & 12,12 \\
\hline \multirow[t]{6}{*}{ Games-Howell } & \multirow[t]{2}{*}{ Esquerda } & Centro & $-39,98^{*}$ & 3,93 & $0,000^{*}$ & $-49,42^{*}$ & $-30,53$ \\
\hline & & Direita & $-44,32^{*}$ & 3,20 & $0,000^{*}$ & $-52,01^{*}$ & $-36,62$ \\
\hline & \multirow[t]{2}{*}{ Centro } & Esquerda & $39,98^{*}$ & 3,93 & $0,000^{*}$ & $30,53^{*}$ & 49,42 \\
\hline & & Direita & $-4,34$ & 3,36 & 0,407 & $-12,48$ & 3,80 \\
\hline & \multirow[t]{2}{*}{ Direita } & Esquerda & $44,32^{*}$ & 3,20 & $0,000^{*}$ & $36,62^{*}$ & 52,01 \\
\hline & & Centro & 4,34 & 3,36 & 0,407 & $-3,80$ & 12,48 \\
\hline
\end{tabular}

Fonte: Elaboração própria

Nota: * As diferenças entre as médias são significativas.

Tabela 7A - Subconjuntos homogêneos: médias da face pública total por campo ideológico

\begin{tabular}{lllcr}
\hline & Campos ideológicos & N & \multicolumn{2}{c}{ Subconjunto para alfa $=\mathbf{0 , 0 5}$} \\
\cline { 3 - 4 } Scheffe & & & $\mathbf{1}$ & $\mathbf{2}$ \\
& Esquerda & 37 & 43,04 & 83,02 \\
& Centro & 29 & & 87,35 \\
& Direita & 25 & & 0,512 \\
Ryan-Einot- & Sig. & & 1,000 & 83,02 \\
Gabriel-Welsch F F & Centro & 37 & 43,04 & 87,35 \\
& Direita & 29 & & 0,271 \\
\hline
\end{tabular}

Fonte: Elaboração própria. 
Tabela 8A - Estatísticas descritivas: face pública total por origem do partido

\begin{tabular}{|c|c|c|c|c|c|c|c|c|}
\hline & \multirow[t]{2}{*}{$\mathbf{N}$} & \multirow[t]{2}{*}{ Média } & \multirow{2}{*}{$\begin{array}{l}\text { Desvio } \\
\text { padrão }\end{array}$} & \multirow{2}{*}{$\begin{array}{l}\text { Modelo } \\
\text { padrão }\end{array}$} & \multicolumn{2}{|c|}{ Intervalo de confiança de $95 \%$ para média } & \multirow[t]{2}{*}{ Mínimo } & \multirow[t]{2}{*}{ Máximo } \\
\hline & & & & & Limite inferior & Limite superior & & \\
\hline Externa & 16 & 39,34 & 14,95 & 3,74 & 31,37 & 47,30 & 18,18 & 66,67 \\
\hline Mista & 21 & 45,86 & 17,12 & 3,74 & 38,07 & 53,65 & 12,50 & 69,57 \\
\hline Interna & 54 & 85,03 & 12,87 & 1,75 & 81,51 & 88,54 & 40,00 & 100,00 \\
\hline Total & 91 & 67,95 & 25,18 & 2,64 & 62,71 & 73,20 & 12,50 & 100,00 \\
\hline
\end{tabular}

Fonte: Elaboração própria

Nota: Face pública total: mandatários eleitos e ocupantes de cargos de confiança. Origem externa: PT. Mista: PSB e PDT. Interna: PSDB, PMDB, PFL/DEM e PP.

Tabela 9A - ANOVA: comparação entre médias da face pública total por origem do partido

\begin{tabular}{lccccc}
\hline & $\begin{array}{c}\text { Soma dos } \\
\text { quadrados }\end{array}$ & df & Quadrado médio & F & Sig. \\
\hline Entre Grupos & 39092,14 & 2 & 19546,07 & $0,000^{*}$ \\
Nos grupos & 17988,22 & 88 & 204,41 & \\
Total & 57080,36 & 90 & & & \\
\hline
\end{tabular}

Fonte: Elaboração própria

Nota: * As diferenças entre as médias são significativas.

Tabela 10A - Testes de robustez da igualdade de médias: médias da face pública total por origem do partido

\begin{tabular}{lcccc}
\hline & Estatística & df1 & df2 & Sig. \\
\hline Welch & 88,45 & 2 & 31,18 & $0,000^{*}$ \\
Brown-Forsythe & 81,96 & 2 & 46,53 & $0,000^{*}$ \\
\hline
\end{tabular}

Fonte: Elaboração própria.

Nota: * As diferenças entre as médias são significativas. 
Tabela 11A - Testes Post hoc de comparações múltiplas: médias da face pública total por origem do partido

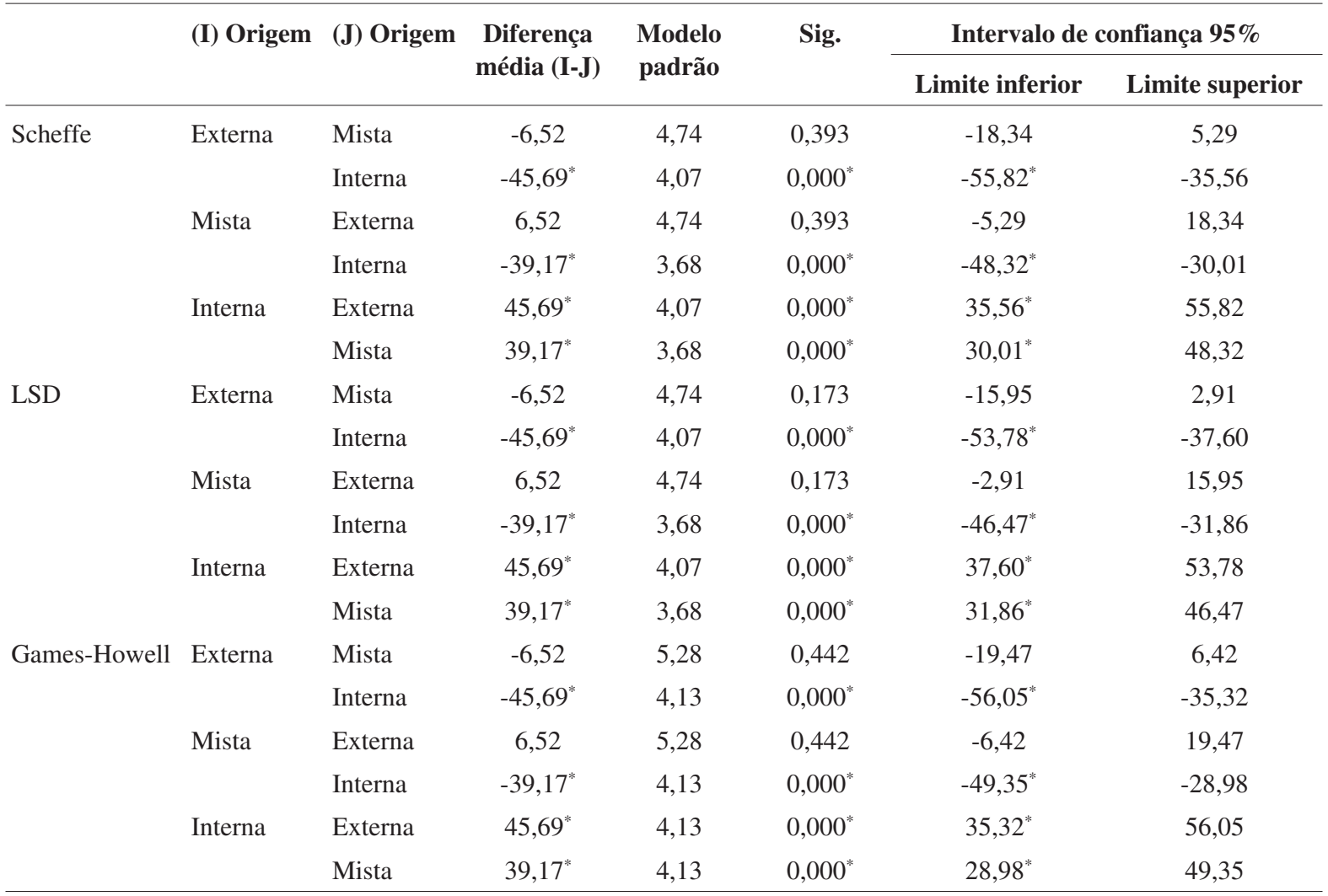

Fonte: Elaboração própria

Nota: * A diferença entre as médias é significativa.

Tabela 12A - Subconjuntos homogêneos: médias da face pública total por origem do partido

\begin{tabular}{lllcc}
\hline & Origem & N & Subconjunto para alfa $=\mathbf{0 , 0 5}$ \\
\cline { 4 - 4 } Scheffe & & & $\mathbf{1}$ & $\mathbf{2}$ \\
& Externa & 16 & 39,34, \\
& Mista & 21 & 45,86, & 85,03 \\
& Interna & 54 & & 1,000 \\
Ryan-Einot-Gabriel-Welsch F & Sig. & & 0,302 & 39,34 \\
& Externa & 16 & 45,86 & 85,03 \\
& Mista & 21 & & 1,000 \\
\hline
\end{tabular}

Fonte: Elaboração própria. 
Gráfico 1A - Dirigentes com cargos eletivos ou de confiança (\%) nas executivas formadas no governo e nas executivas formadas na oposição (médias)

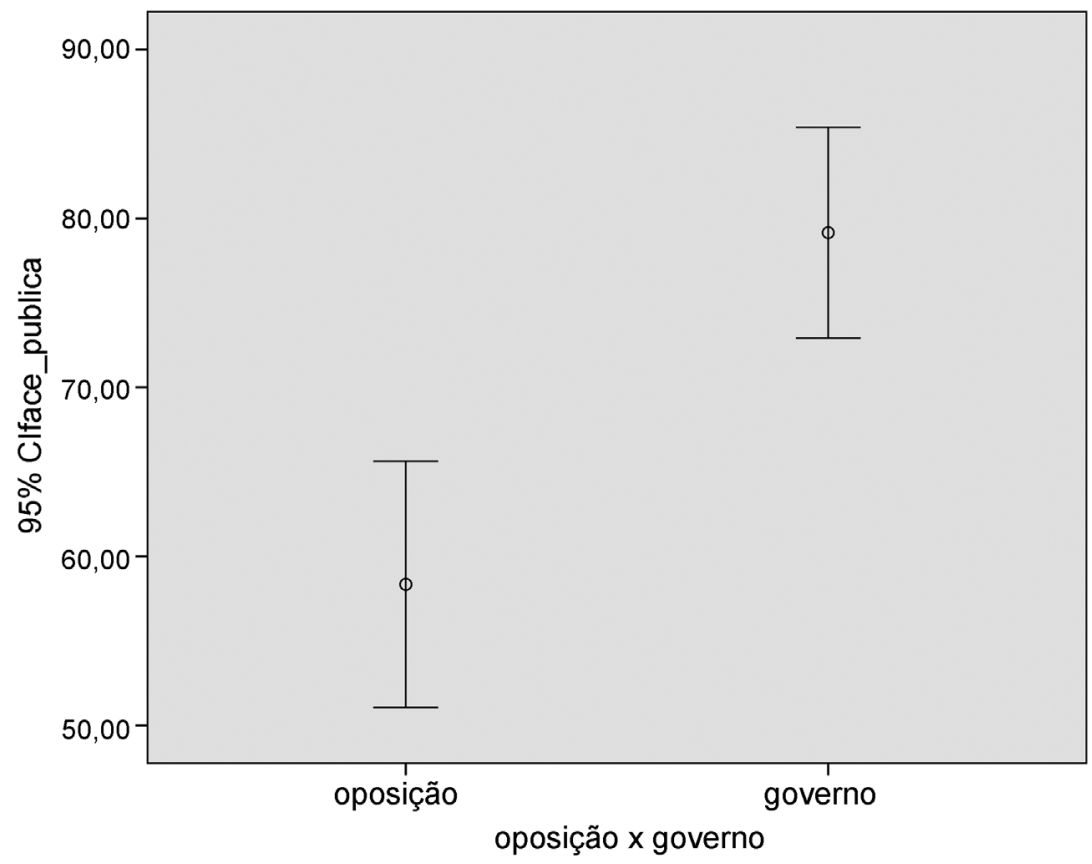

Fonte: elaborado a partir das tabelas do Apêndice 2

Nota: Foi calculada a média da participação total da face pública (ocupantes de cargos de confiança e mandatários eleitos) nas executivas formadas quando o respectivo partido integrava a coalizão de apoio ao governo federal $(\mathrm{N}=42)$; e o mesmo cálculo para as executivas constituídas quando o partido fazia parte da oposição $(\mathrm{N}=49)$. Os integrantes das coalizões governistas na Câmara foram coletados em Figueiredo e Limongi (2007).

Gráfico 2A - Dirigentes sem histórico de cargos (\%) nas executivas formadas no governo e nas executivas formadas na oposição (médias)

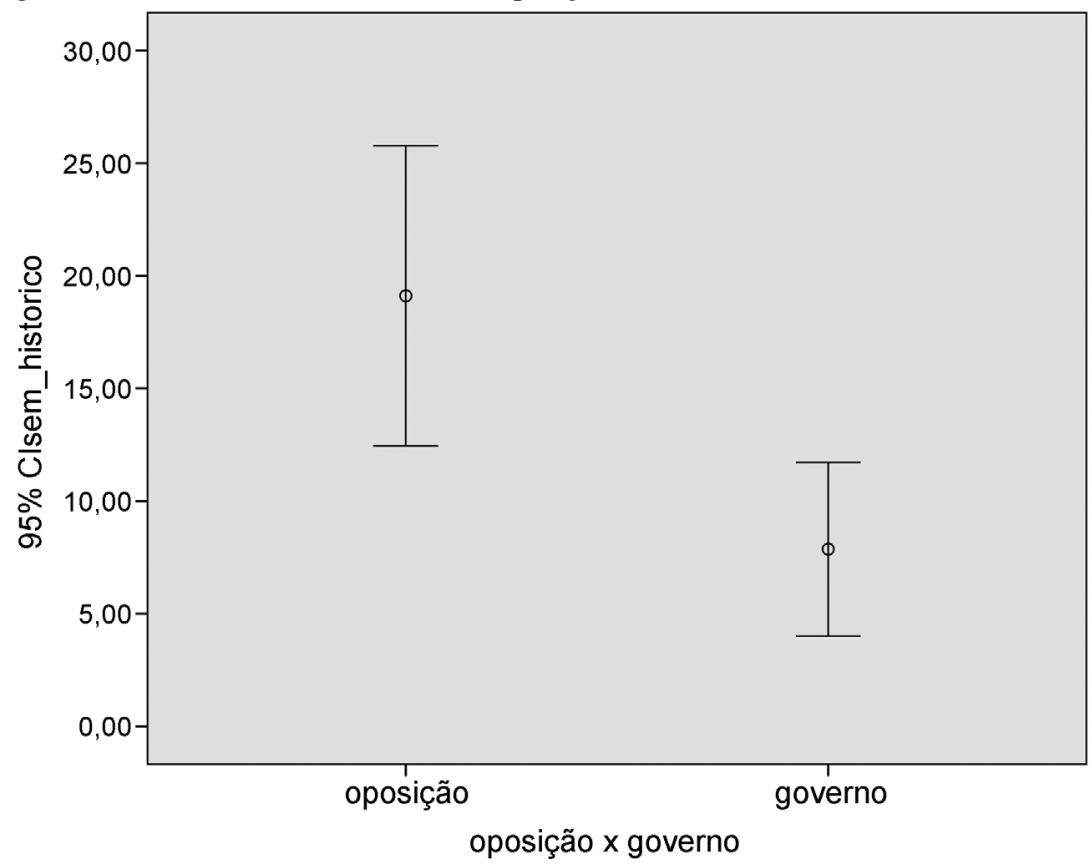

Fonte: elaborado a partir das tabelas do Apêndice 2. 


\section{Apêndice 2. Dados desagregados por partido}

Tabela 1B - Executivas Nacionais do PFL/DEM, 1984-2011 (\%)

Tabela 2B - Executivas Nacionais do PDS/PPR/PPB/PP, 1980-2009 (\%)

Tabela 3B - Executivas Nacionais do PSDB, 1988-2013 (\%)

Tabela 4B - Executivas Nacionais do PMDB, 1980-2013 (\%)

Tabela 5B - Executivas Nacionais do PDT, 1980-2013 (\%)

Tabela 6B - Executivas Nacionais do PSB, 1985-2011 (\%)

Tabela 7B - Executivas Nacionais do PT, 1980-2013 (\%) 


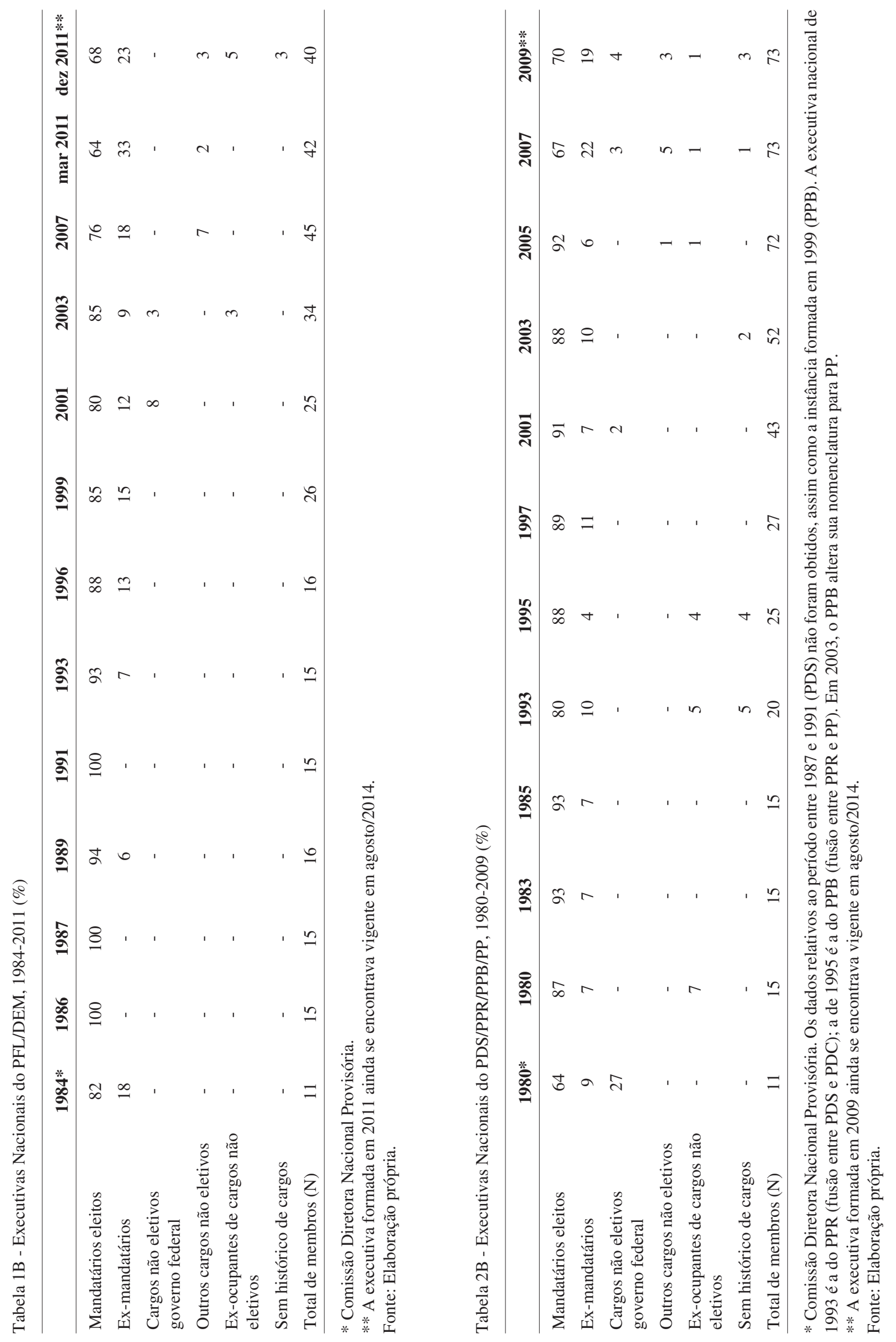



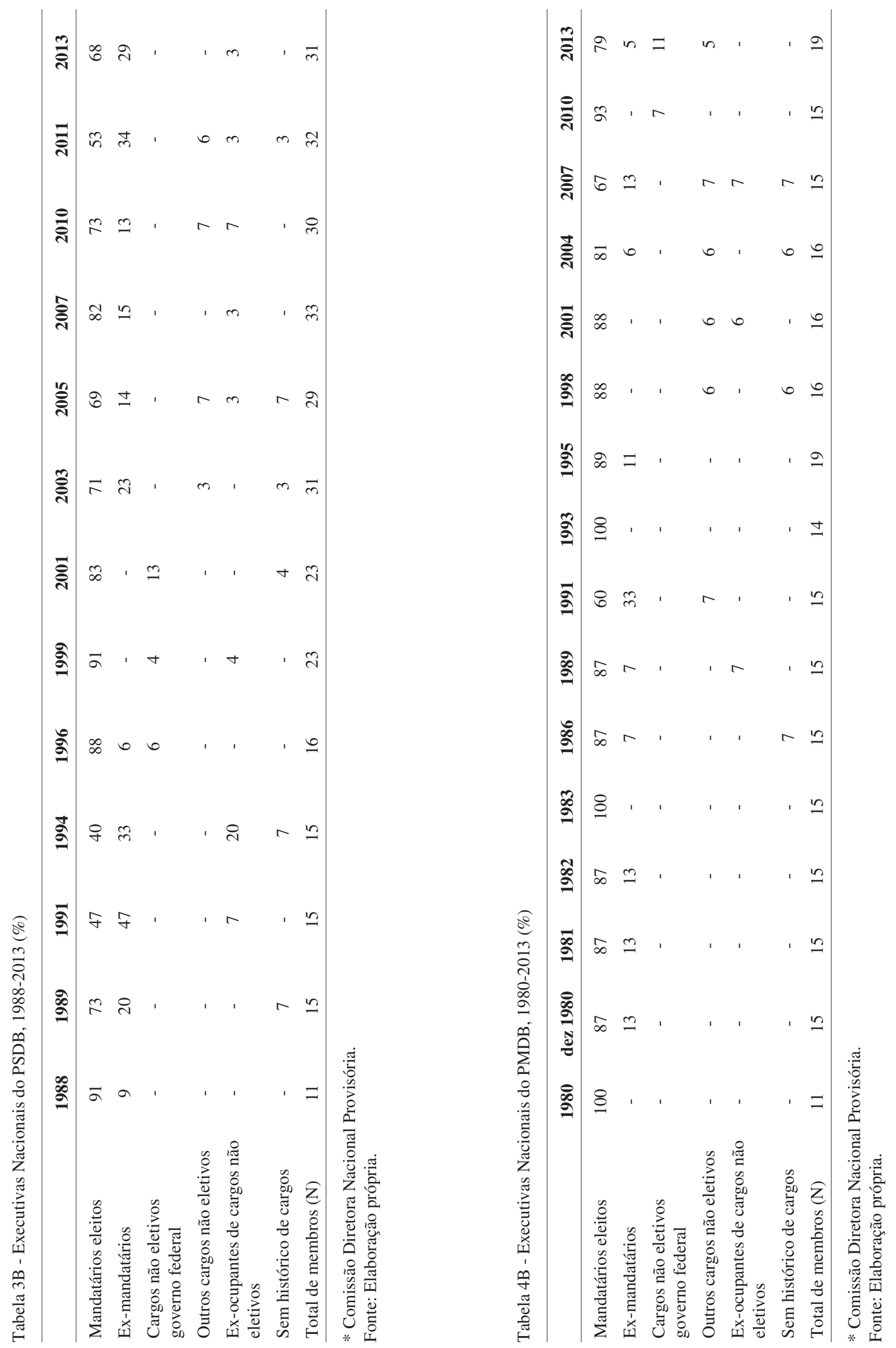


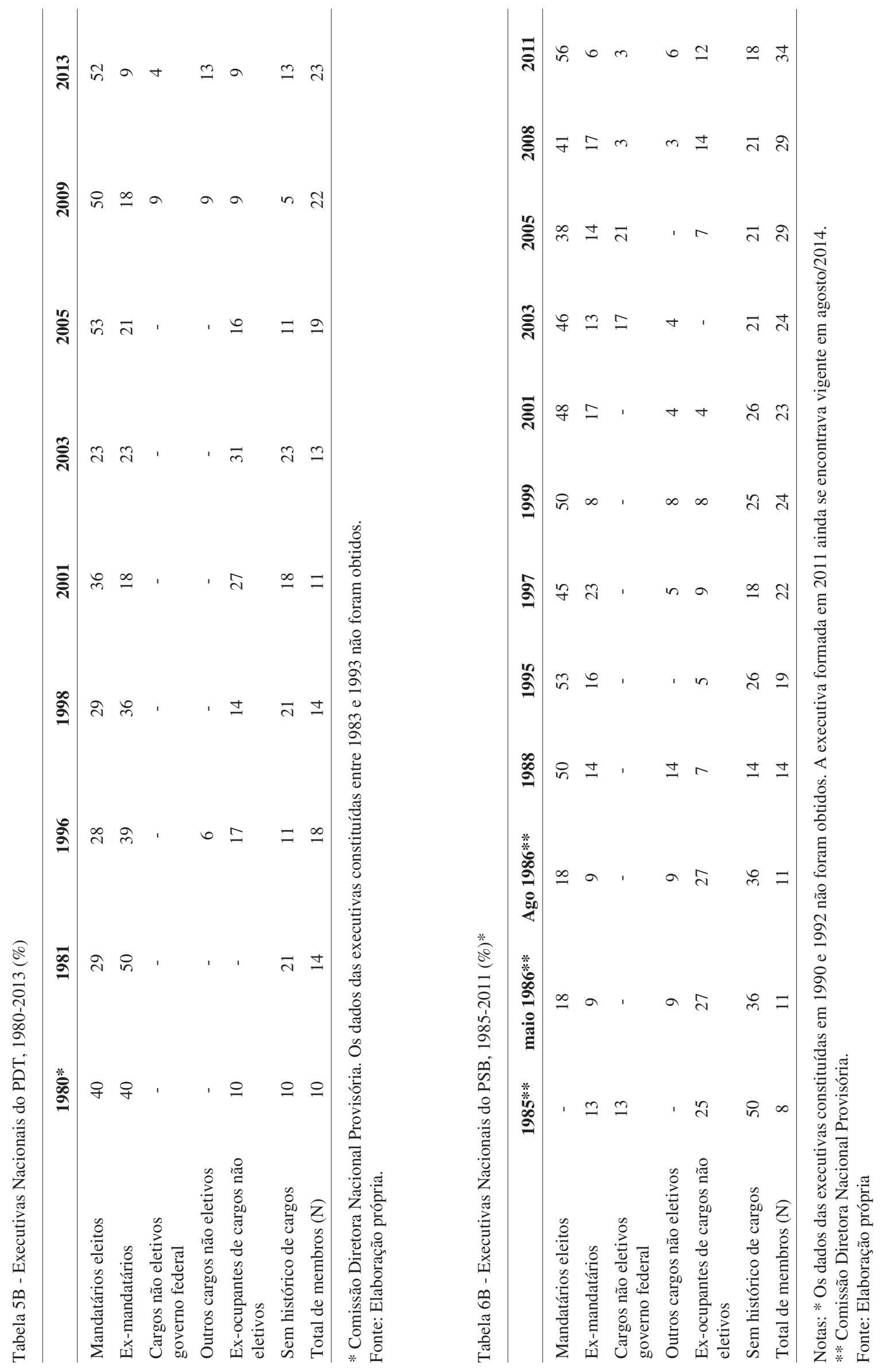




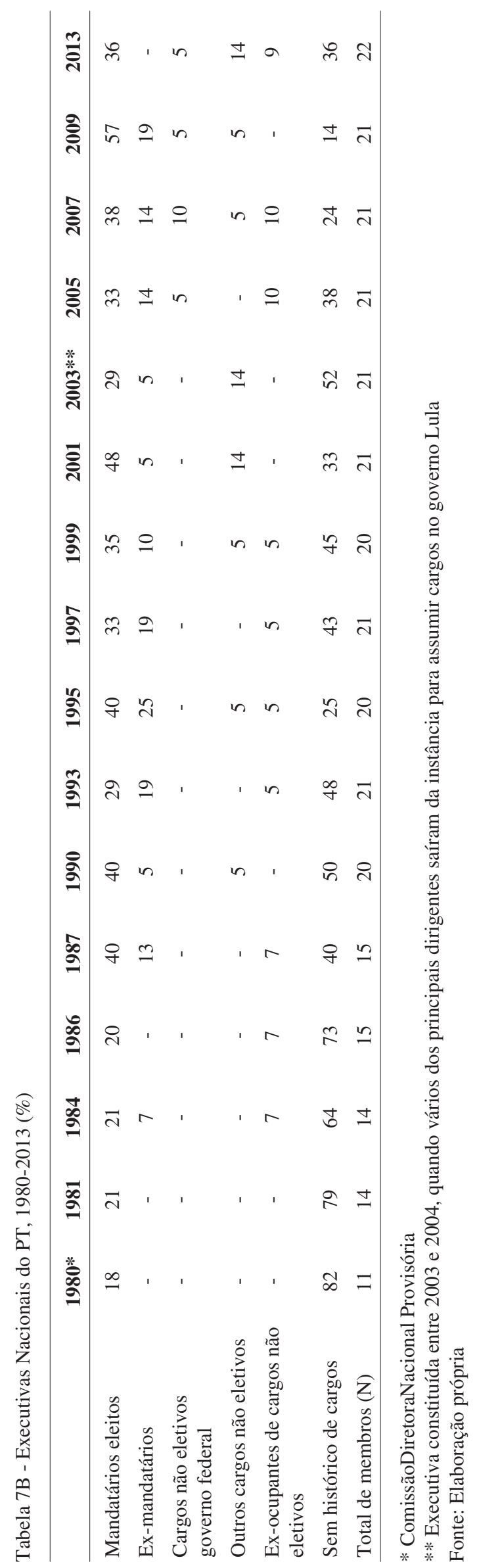

